فاعلية استخدام منصة التعليم الاكتروني Google class room علي تتمية المهارات التدريسية والاتجاه نحو التعلم عبر الانترنت لدي طلاب التدريب الميداني بكلية التربية

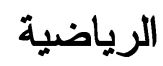

م.د/ اسلام جمال الدين أحمد خضر

مدرس دكتور بقسم مناهج وطرق تدريس التربية الرياضية

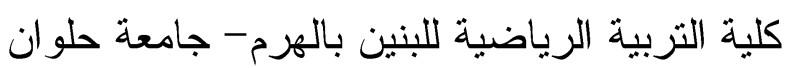

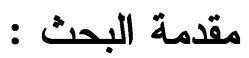

فرضت النطورات التكنولوجية و المعلوماتية نفسها على جميع مناحي الحياة مما جعـل

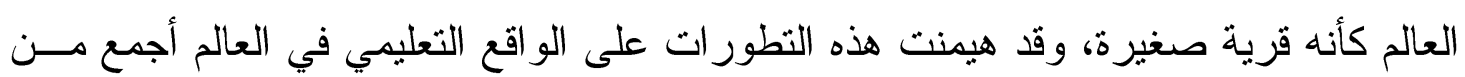

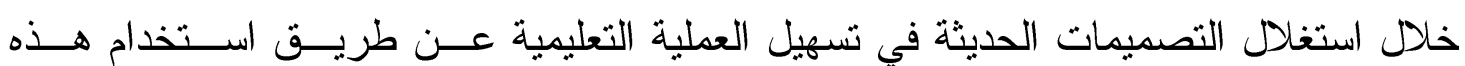
التصميمات في التدريس وعلى مدار العقود الماضية نم استخدام العديد من البرمجيات و البيئات التعليمية في التدريس بدءاً من الحاسوب ببرمجياته البسيطة مروراً بالتعلم الالكتروني و التعليم

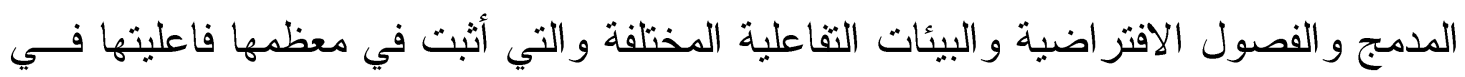
التعليم.

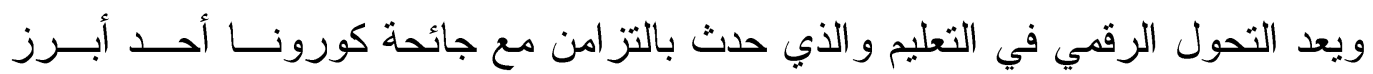

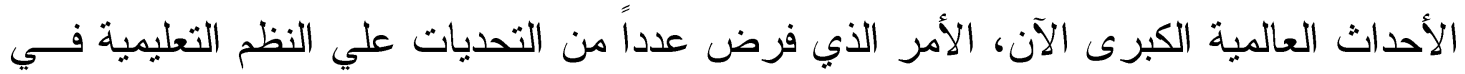

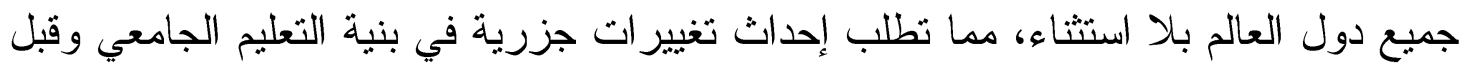

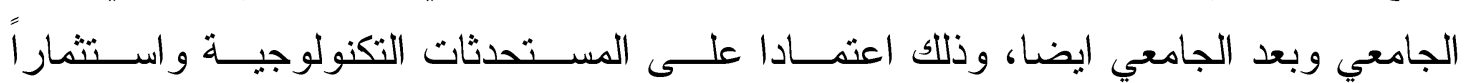

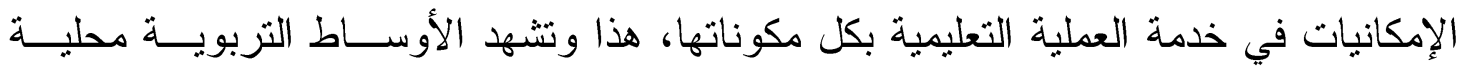

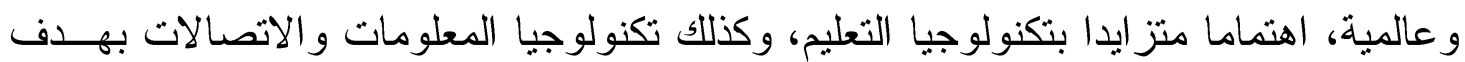
تطوير الو اقع التربوي ورفع مستوي مخرجات التعليم الأمر الذي حمل في طياته حتمية التغيير

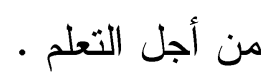

ولعل أكبر إسهام في مجال التزبية هو مجال التعليم عن بعــ Distance Education

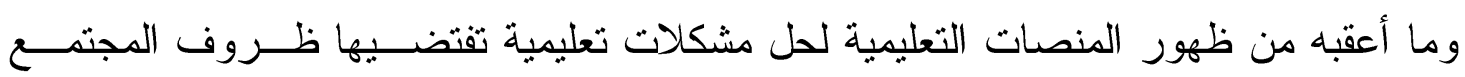
و التغير الاجتماعي و التكنولوجي السريع، فهو يعمل على تهيئة فرص تعليمية وتدريبية لنوعية

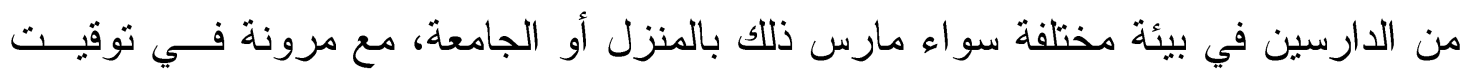

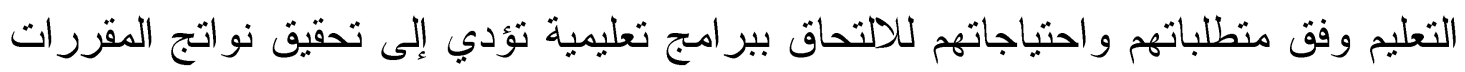

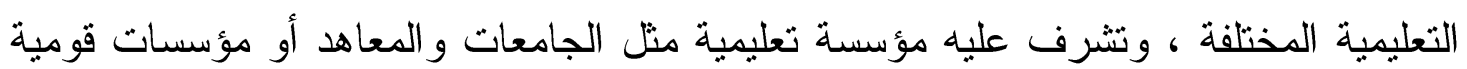
أو عالمية بالاعتماد على نظم للاتصال بالدارسين لتحقيق المتابعة و التفاعلية ـ ( 1 : 14 ) 
وتعد إدارة المعرفة أحد التطورات الفكرية المعاصرة التي جاءت نتيجة ثورة الاتصالات و تكنولوجيا المعلومات و التدفق الهائل لحجم المعرفة و المعلومات في الحياة اليوميــة وســر عة توليدها و العمل المستمر على تتظيمها و المحافظة عليها و الاستفادة القصوى منها، ومشــاركتها وتطبيقها وتشجيع الإبداع، وتسعي أنظمة إدارة التعلم التي تعرف بمنصات التعليم الاكتروني إلى إنشاء بيئة تعليمية إلكترونية تعاونية تشاركيه عن طريق تطوير بر امج تعليمية على الشبكة

\section{$(111: 8)$}

وظهرت منصات التعليم الإلكترونية لتقدم تعليم منميز وتنافست الشركات العالمية فـي انتاج تلك المنصـات التي يمكن من خلالها إدارة التعلم بسهولة ويسر، وهي تقـــدم مجموعــة متتوعة من الأدوات التي تتيح التو اصل و المشاركة و النقاش مع امكانية إنشاء مجموعات العمل

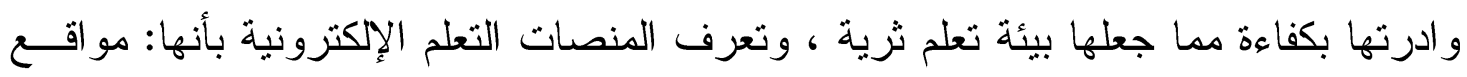
تعليمية تتيح للطلاب تبادل النقاش، و الأفكار، ومشاركة المحتوي وتوزيــع الأدوار وإجــراء الاختبار ات و الو اجبات إلكترونيا ـ ( 3 : 112 ) وتعد المنصات التعليمية من أشهر المستحدثات التكنولوجية التي وفرت للمعلم و المــتعلم خصائص عديدة يسرت العملية التعليمية، ولقد حققت المنصات التعليمية في السنوات الأخيـرة حضوراً عالميا في مر احل التعليم مما أدي إلى ظهور أنماط تعليمية أكثر تفاعلية ، و المنصات التعليمية باعتبار ها مجموعة متكاملة من الأدوات على شبكة الانترنت تزكز بشكل خاص على ملى الدعم التعليمي لتقديم المحتوى، وتمكين التو اصل و التتظيم و الدعم التزبوي • ( 9 : ^ود) وتسهم منصات التعلم الإككترونية من خلال نوظيف أدوات المناقشة اللا تز امنية في إتمام

الأنشطة، و المهام التعليمية، وتحسين التعلم • ( 2 : 459 - 544 )

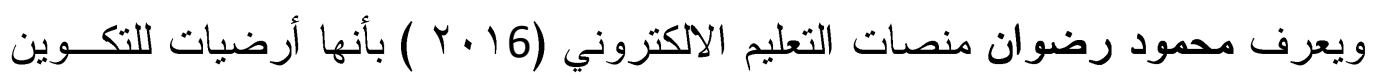
عن بعد قائمة على تكنولوجيا الويب ، وهي بمثابة الساحات التي يتم بواسطتها عرض الأعمال وجميع ما يختص بالتعليم الإلكتروني وتشمل المقررات الإلكترونية وما تحتويه من نشــاطات

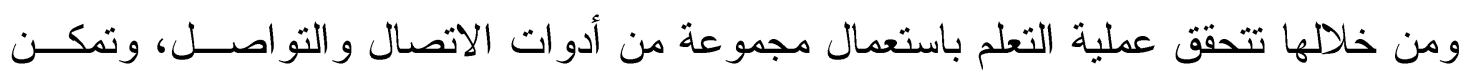
الطالب من الحصول على ما يحتاجه من مقررات دراسية وبر امج ... الخ • كما عرفها عماد أبو شنب و آخرون (11) بأبها أنظمة تشاعد وتعزز العملية التعليمية ، حيث تمكن المعلم من إعداد المواد التعليمية ومصادر ها على موقع النظام، كما توفر غرفـــة الحوار و غيرها من الخدمات الإلكترونية المساندة للعملية التذريسية ولقد نادت العديد من الدراسات بضرورة استخدام منصات التعليم في التدريس الجامعي نتيجة لدور ها الفعال تتمية الكفاءة التو اصلية وتتمية مهار ات التفكير وحل المشكلات وزيــادة 
التعلم الذاتي المستمر كدر اسة " وليد سالم محمد الحلفاوي ومروة ذكي توفيق ذكي ومحمــود

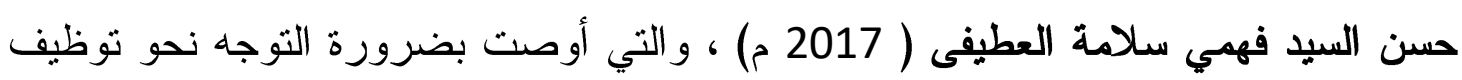

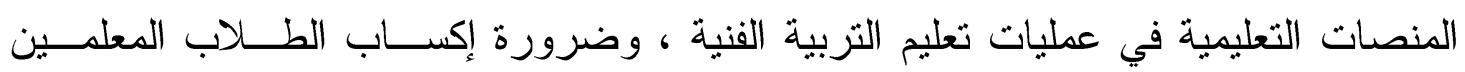

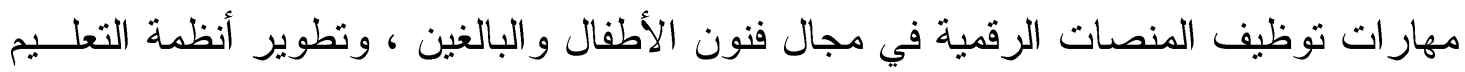

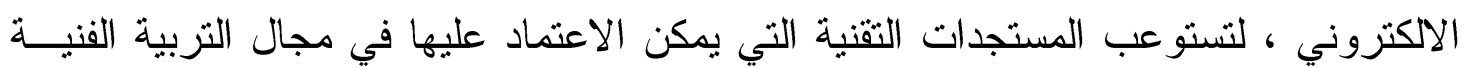
كالمنصات و السحب الحاسوبية ومحركات بحث الصور الرقئية . (9 : 597 - 634 )

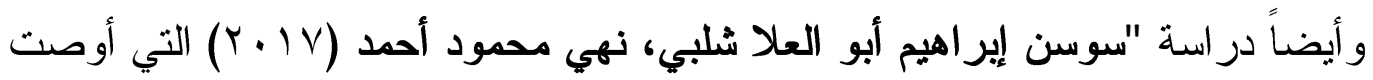

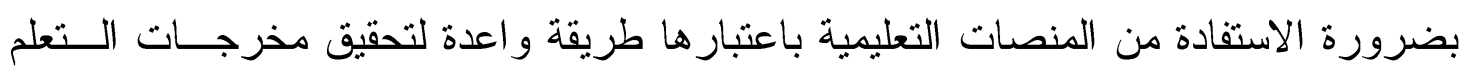

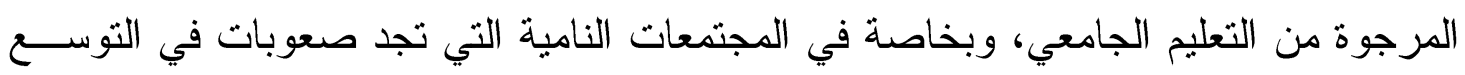

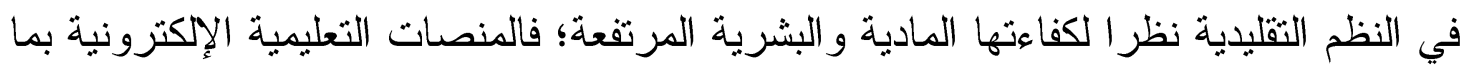
تتضدنه من خصائص وأدوات متعددة نعتمد على مجموعات التفاعل و العمل في فريق، الأمر

الذي يمكن أن يكون مجال خصب للتوسع في التعليم العالي و الجامعي. ( 2 : 109 )

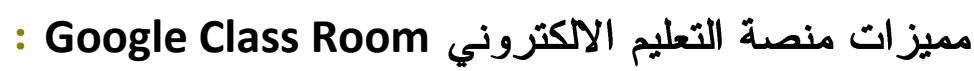
تتميز هذه المنصة بأنها تسهل عمل الطالب و المعلم علي النواحي التالية :

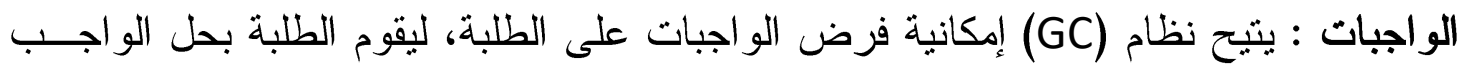

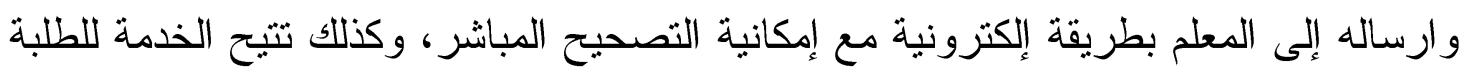

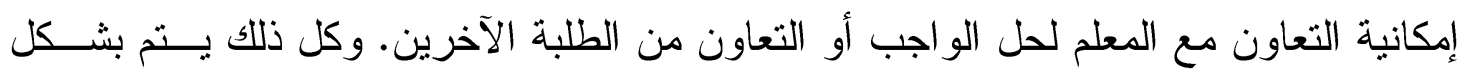

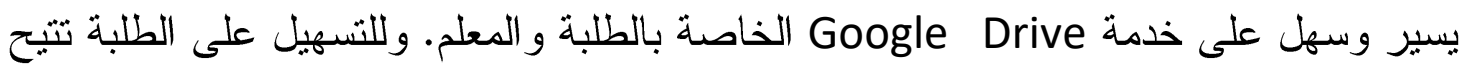

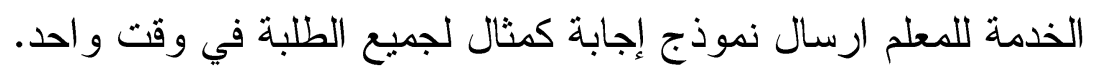

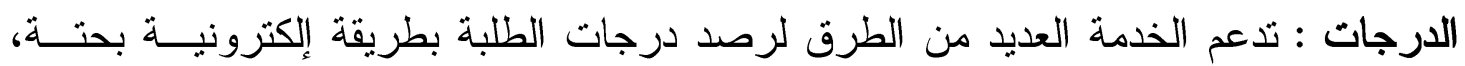

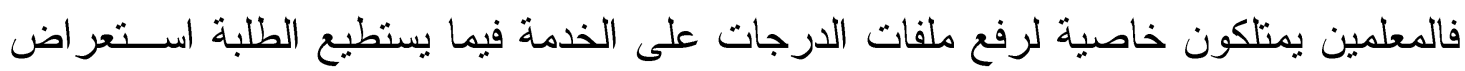

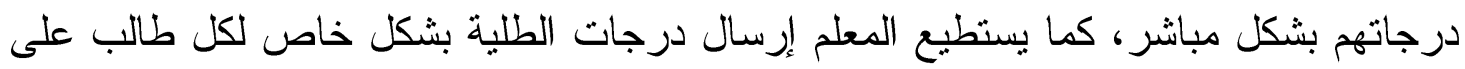

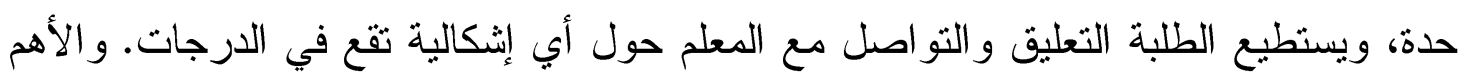

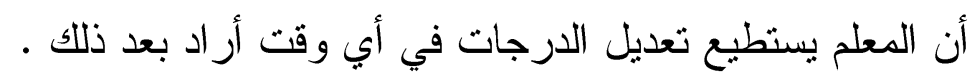

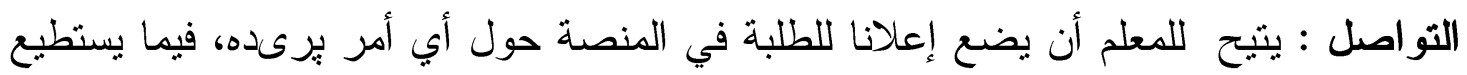

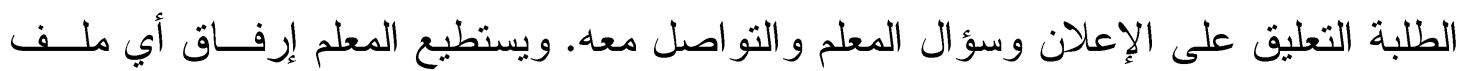

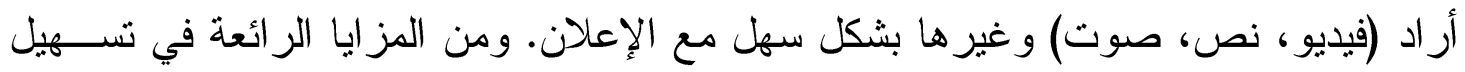

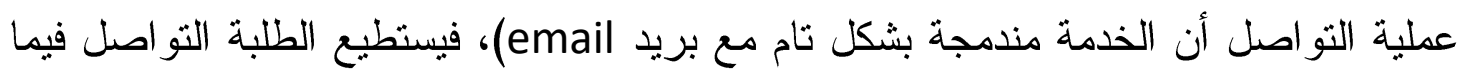

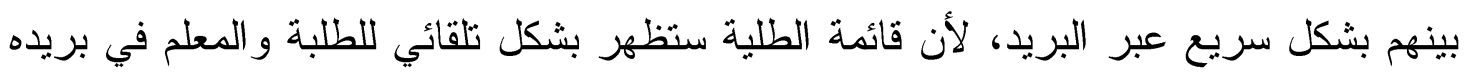




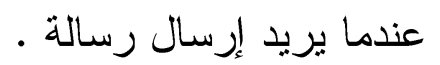

أرشفة الدروس: إذا انتهى وقت مادة أو منهج معين في نهاية العام أو الفصل الدراسي يستطيع

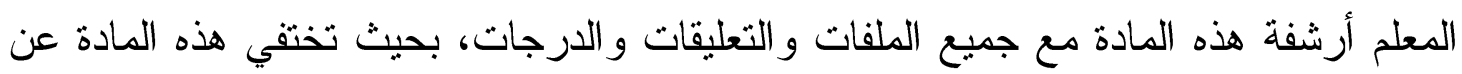

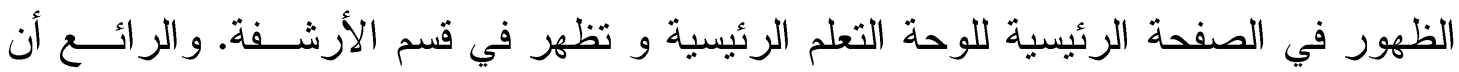
الجميع يستطيعون الوصول إليه في أي وقت أر ادو ا بعد ذلك.

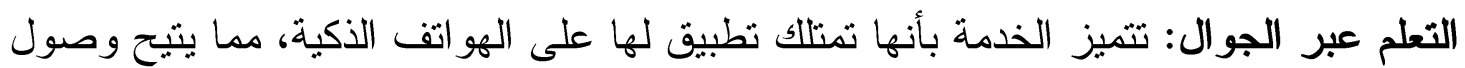

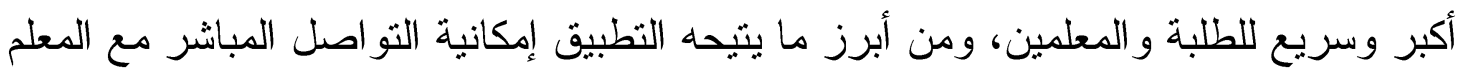

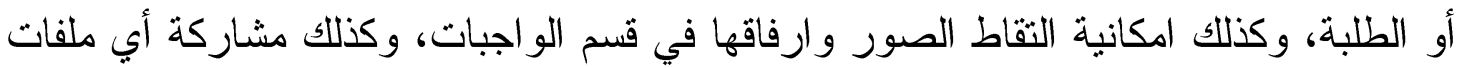

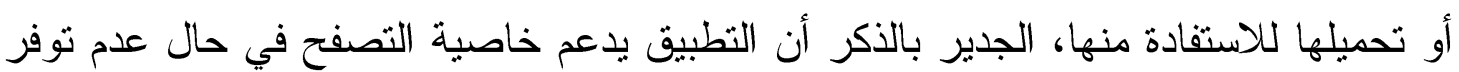

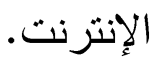

حفظ الوقت: ليصل الطالب إلى المادة أو الصف المطلوب في الخدمة، يمكن للمعلم أن ينشــئ

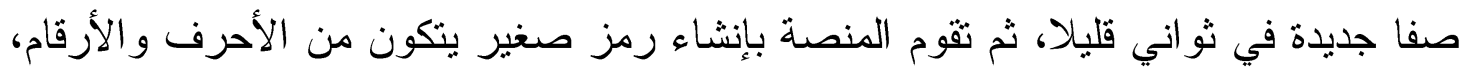

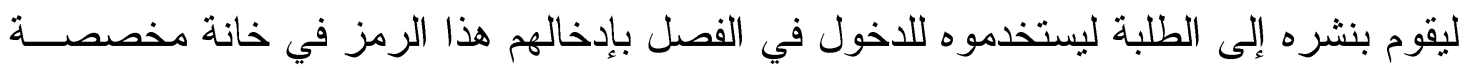

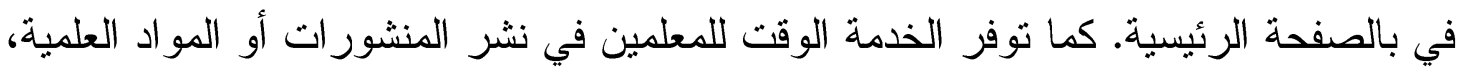

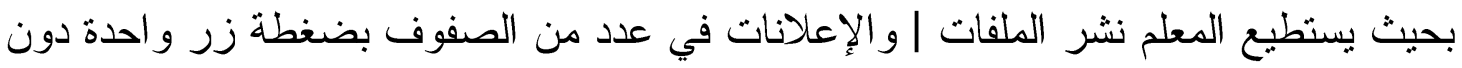

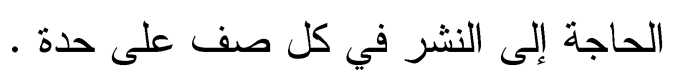

التقويم الدراسي: توفر المنصة خدمة التقويم الدراسي، والذي يتيح الطلبة و المعلمين معرفــة مواعيد الواجبات والاختبار ات والدروس و غيرها من التفاصيل الخاصة، و المميز أنها ترتبط

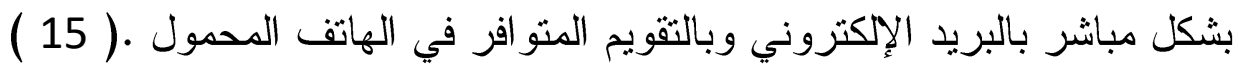

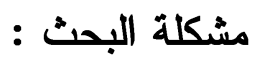

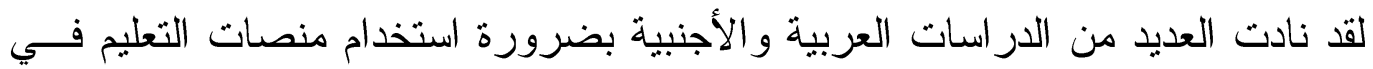

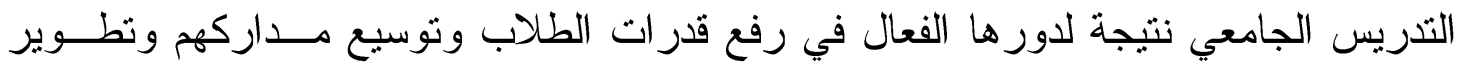
أدائهم الأكاديمي وتتمية الكفاءة التو اصلية وتتمية مهار ات التفكير وحل المشكلات وزيادة التعلم

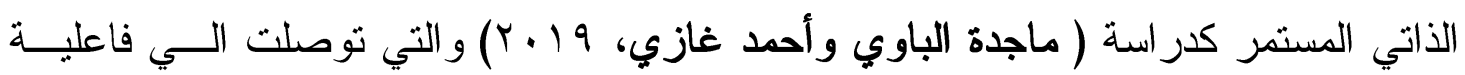
استخدام المنصة التعليمية Google Classroom في تحصيل طلبة قســم الحاسـبات لمسادة I و واتجاهاتهم نحو التعليم الإلكتروني، ودراسـة (Karyawati، 2014) Processing

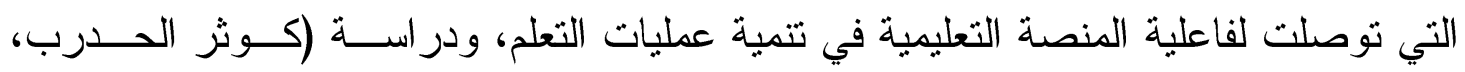

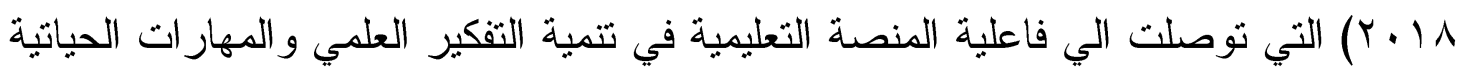

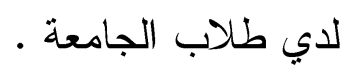


ونتيجة للتقام العلمي و التقني تحولت العملية التعليمية إلى عملية تهتم بأهداف المتعلمين،

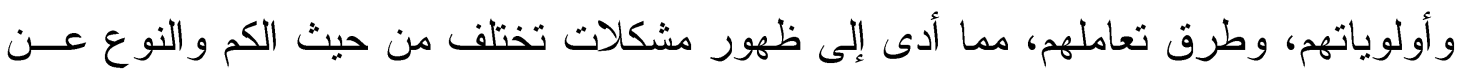

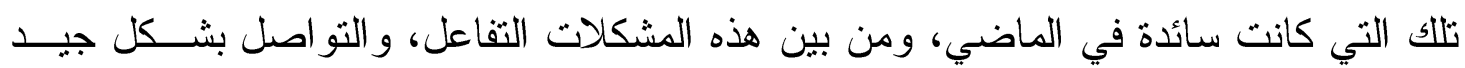
وسريع ، وذللك في ظل وجود العديد من التحديات و التي علي رأسها في الفترة الحالية جائحة

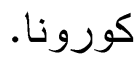

ويعد التدريب الميداني لطلاب كلية التزبية الرياضية من أهم الفترات التي تساهم بشكل

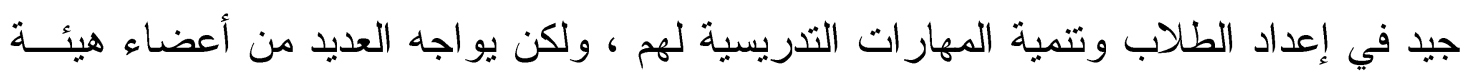

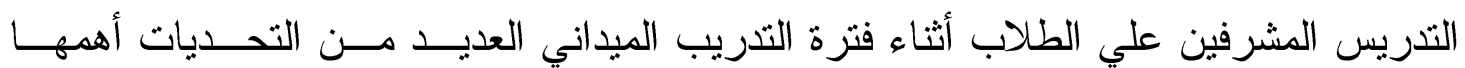

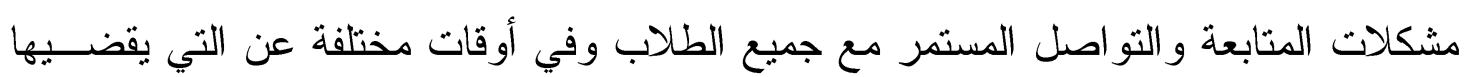

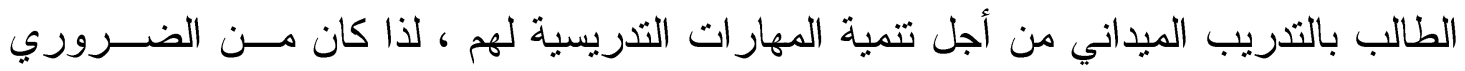

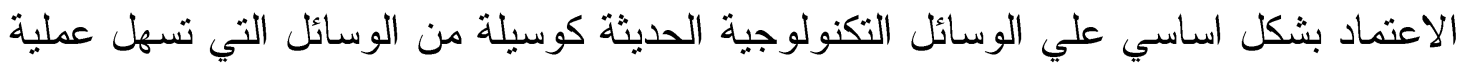

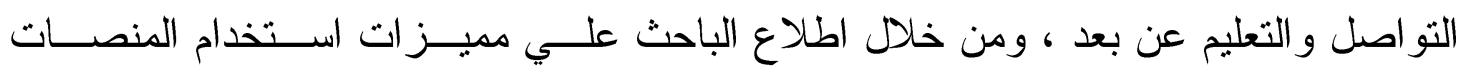

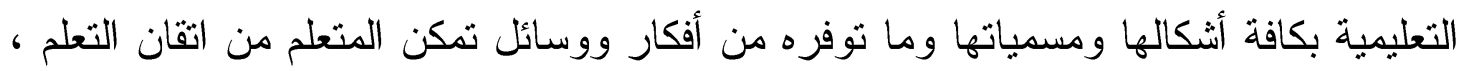

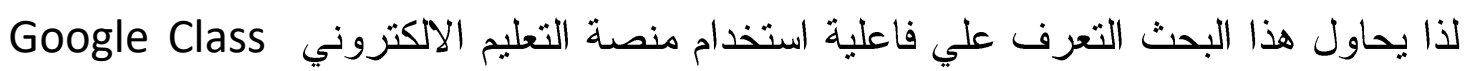
كواحدة من اهم منصات التعليم علي تتمية المهار Room

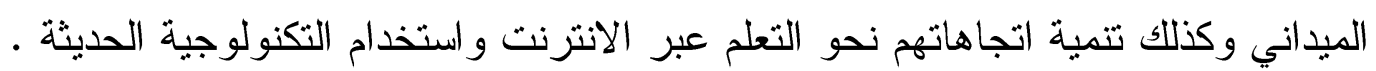
أهــمية البحث :

1. يتتاول هذا البحث أحد المنصات الاكترونية التعليمية الحديثة وهـي منصــة Google

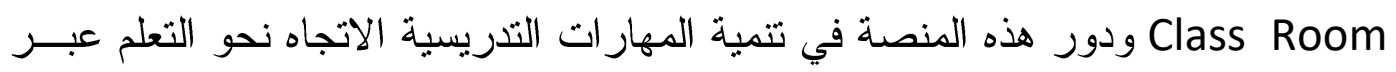
الانترنت .

2. يقلم هذا البحث شرح مفصل لكيفية استخدام المنصة التعليميـة Google Class Room

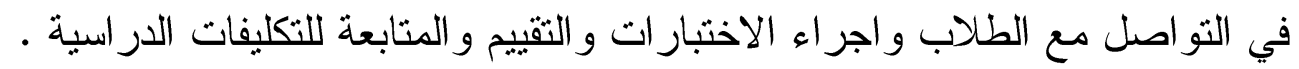

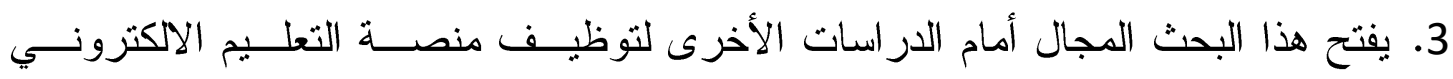

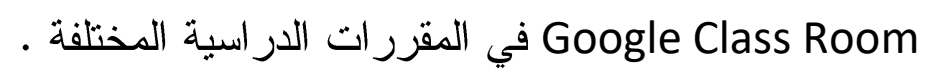

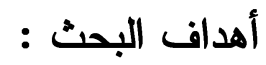
Google Class يهدف البحث إلي التعرف علي فاعلية استخدام منصة التعليم الالكتروني عoom

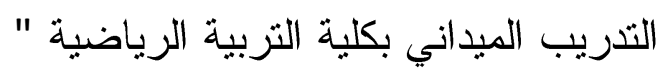




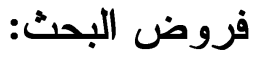

1. يوجد فروق ذات دلالة إحصائية عند مستوى الدلالة بين منوسط المهـار ات التدريسـبة

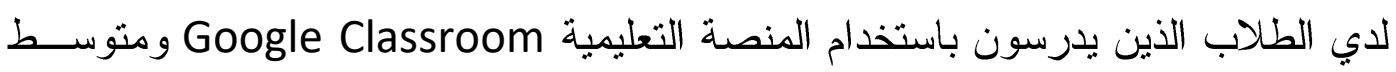

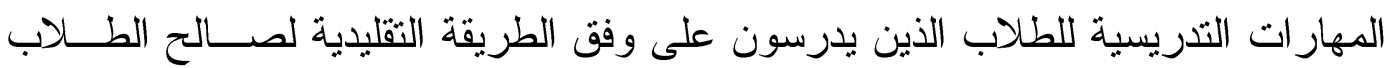
الذين يدرسون باستخدام المنصة التعليمية Google Classroom . 2. يوجد فروق ذات دلالة إحصائية عند مستوى دلالة 0,05 بين متوسط درجــات الاتجــاه

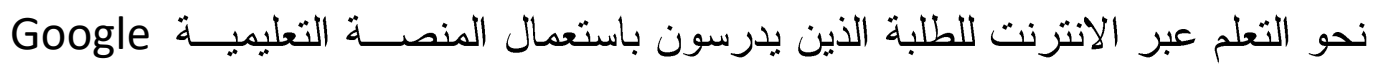

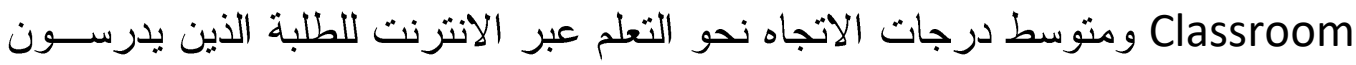

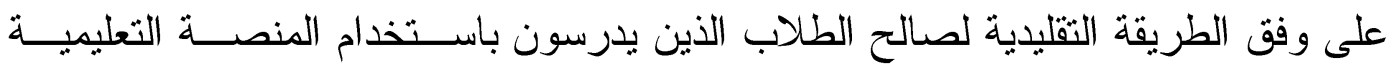

\section{- Google Classroom}

المصطلحات المستخدمة في البحث المنصة التعليمية الاكترونية : عرفتها هناء المسعودي (· ( ب) بأنها "منظومة برمجيه تعليمية

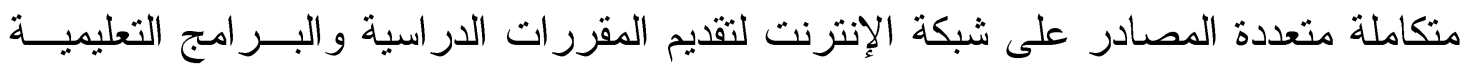

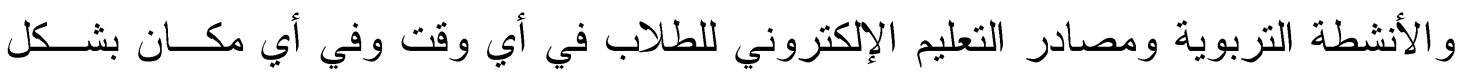

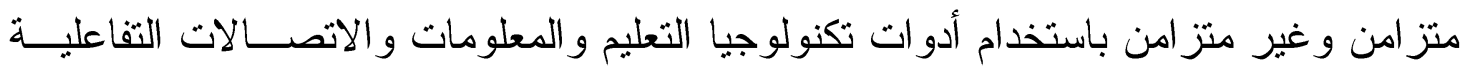
بصوره تمكن المعلم من تقويم الطالب " . منصة التعليم الاكتروني Google class room : يمكن تعريفها إجر ائيا بأنها " بيئة تعليمية

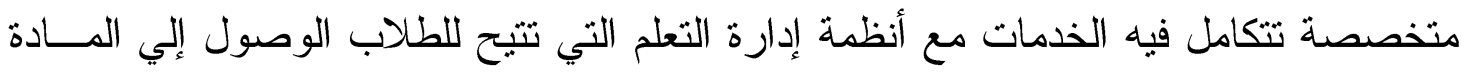

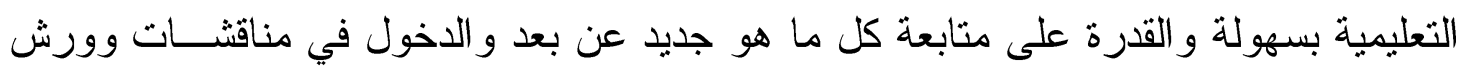

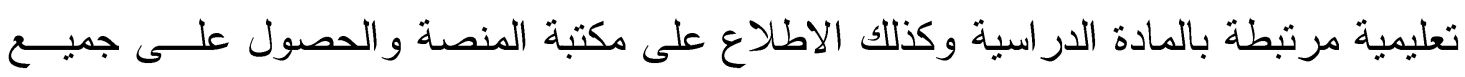

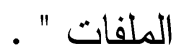
مهارات التدريس الفعال: تعرف بأنها " أنواع من المعارف و المهارات و القــدرات يحصــل

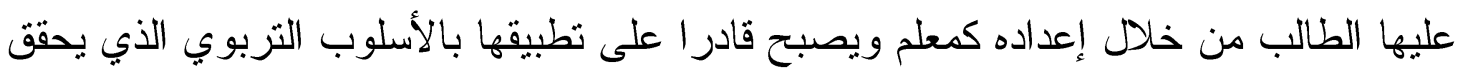

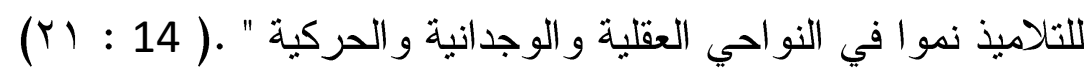
الدراسات السابقة باللغة العربية : 1-در اسة ماجدة ابر اهيم الباوي ، أحمد باسل غازي ( 2019 ) ( 6 ) ) : بعنوان " اثر استخدام

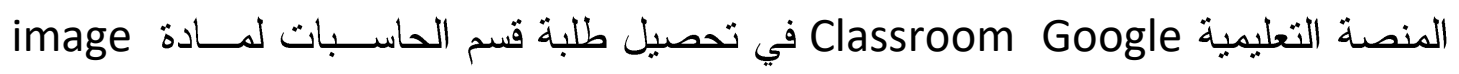

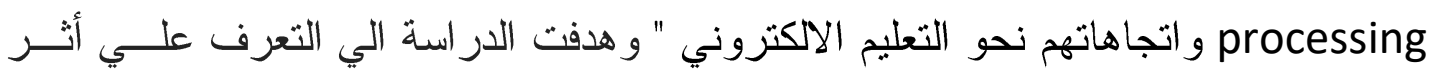

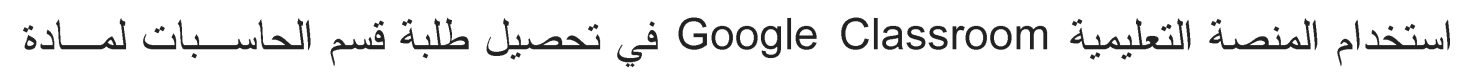


او اتجاهاتهم نحو التعليم الإلكتروني، وقد طبقت تجربة البحث في العام

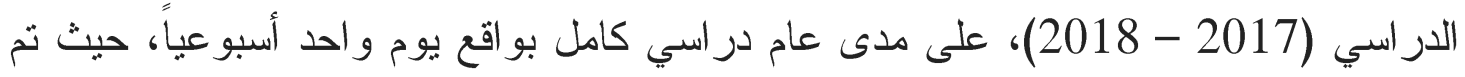

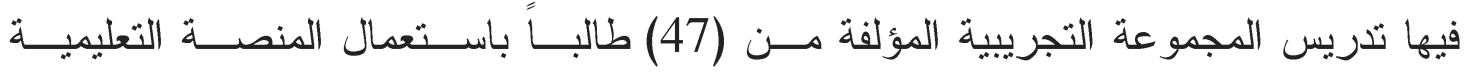
و المجموعة الضابطة المؤلفة من (48) طالباً بالطريقة التقليدية ، واستخدم الباحثــان اختبــار

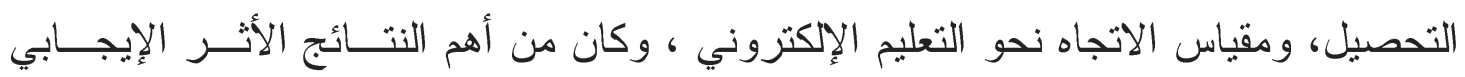

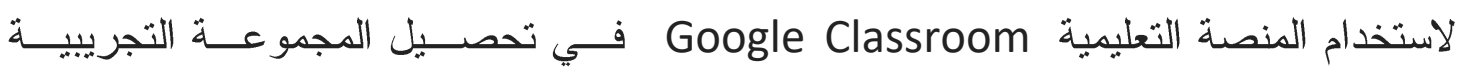
و اتجاهاتهم نحو التعليم الإلكتروني بالمقارنة مع الطريقة التقليدية.

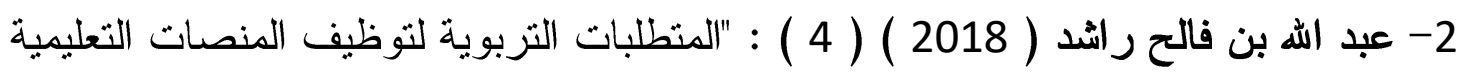

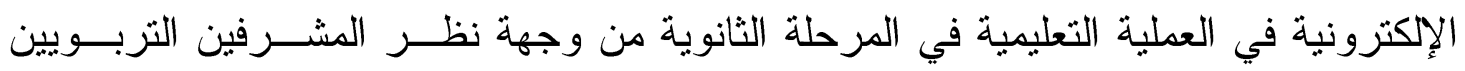

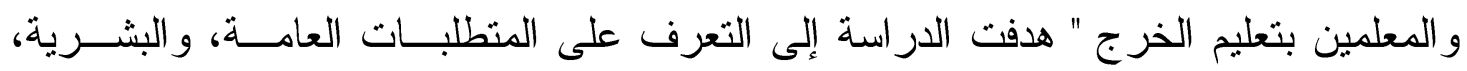

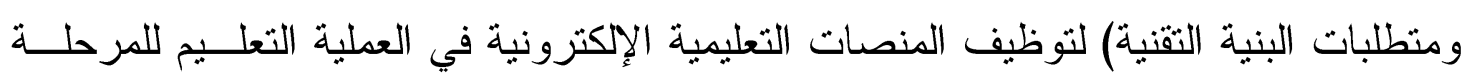

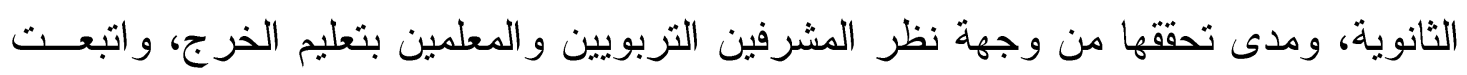

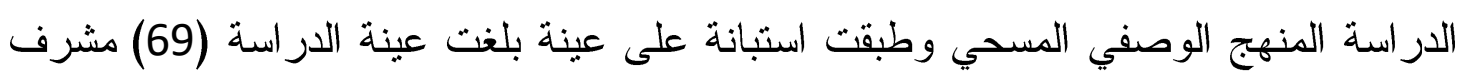

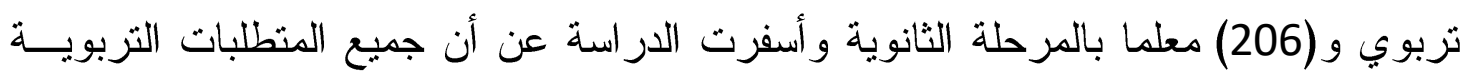

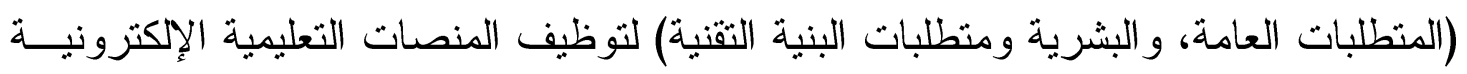

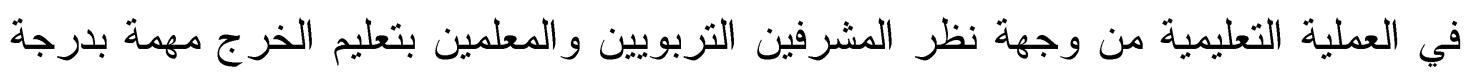

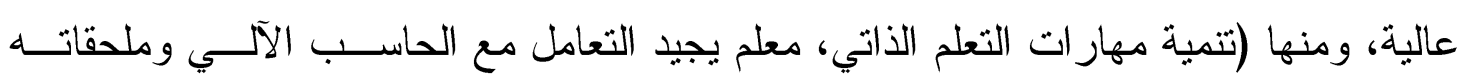
المختلفة وتطبيقات الإنترنت.

3- در اسة محمد حسن حسن رخا ( 2020 ) ( 7 ) بعنوان : " تطبيق نظــام إدارة الــتعلم الإلكتروني "Google Classroom" بكلية التربية الرياضية ببورسعيد أثناء جائحة كورونا:

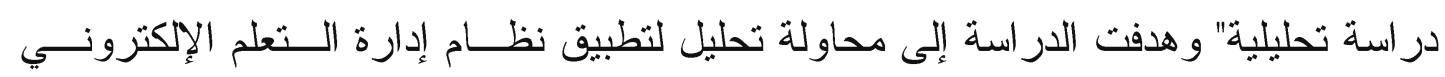

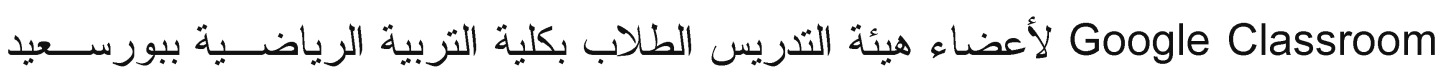

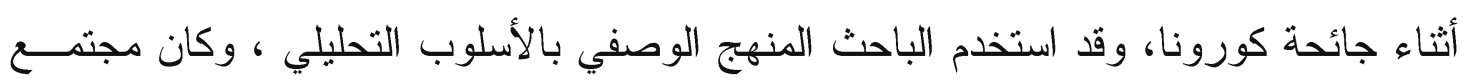

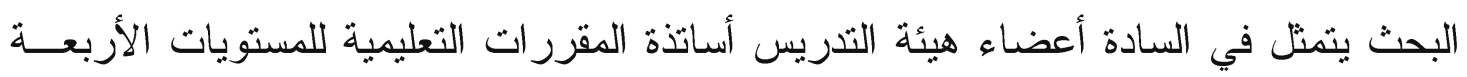

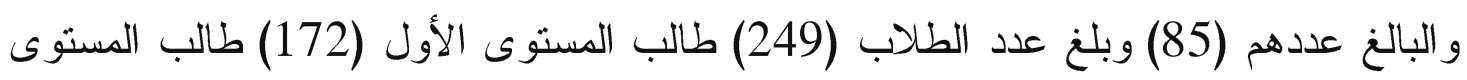

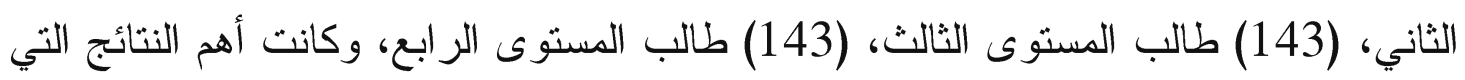

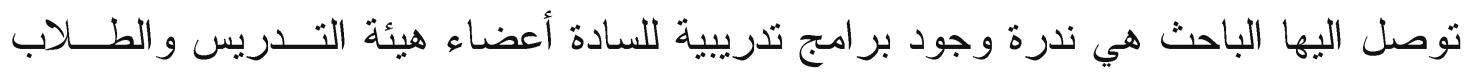

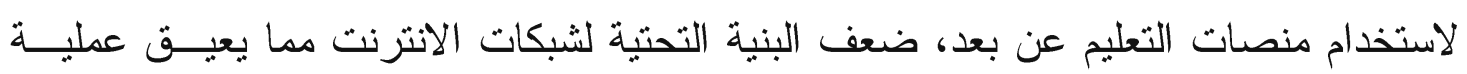
التعلم، الافتقار إلى الأبحاث و الدراسات التي توضح مز بعات ايا وعيوب المنصات التعليمية المختلفة 
للتعليم عن بعد، مما يؤدي إلى صعوبة الاختيار من بينهم، ويوصي الباحث بضرورة تـــوفير

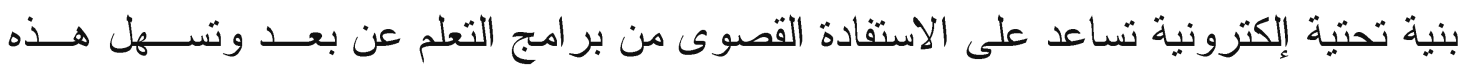

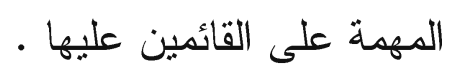
الدر اسات السابقة باللغة الانجليزية :

4- در اسة هولميس ، ويسترنش ، وبونتير(، Tracy , Paunter , Oestreich ، Holmes Google (Park \& Education لتفعيل التعلم النشط، وتعزيز التدريب العملي من خلال قلب الفصول، واستخدام الإنترنت في العملية التعليمية باستخدام تطبيقات Google Education؛ حيث قام البــاحثون

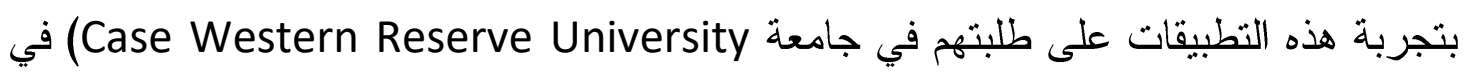

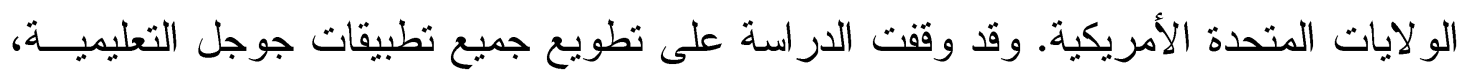

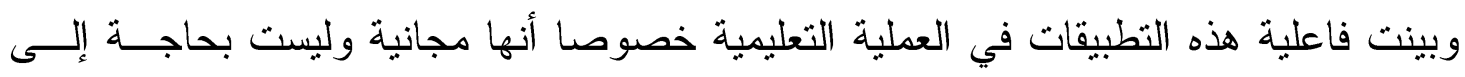
فنيين متخصصين لإدارتها، كما بينت افتقار هذه التطبيقات إلى إدارة تكاملية لربطها مع بعضه ولئه

$$
\text { من خلال لوحة تحكم و احدة. }
$$

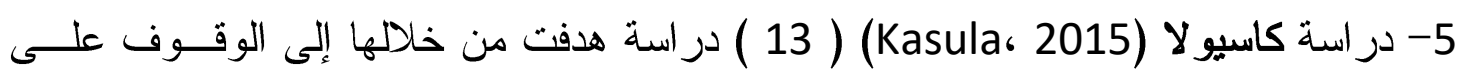

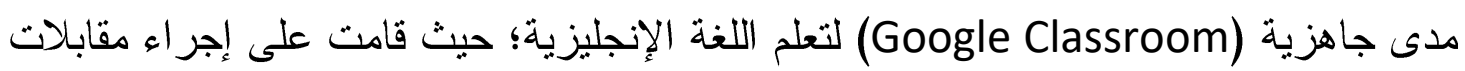

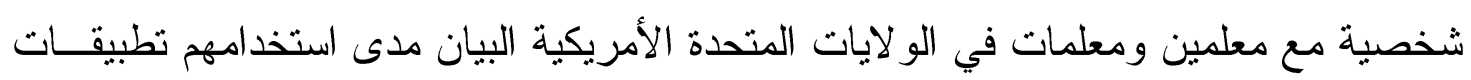

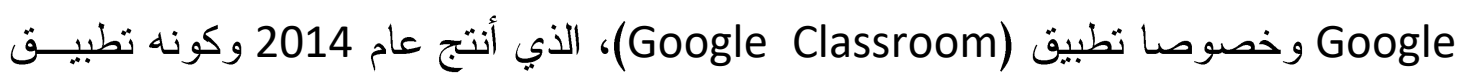
يضم جميع تطبيقات Google Education، وقد بينت الباحثة أن هذا التطبيق المجاني يتـيح

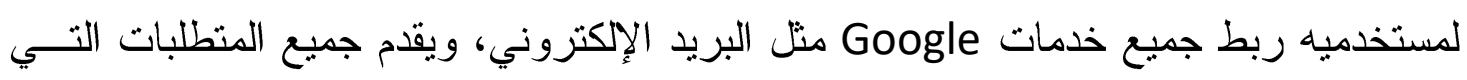
يحتاج إليها المعلم في الغرفة الصفية، ويساهم في التو اصل ما بين المعلم و المتعلم وفي تسهيل

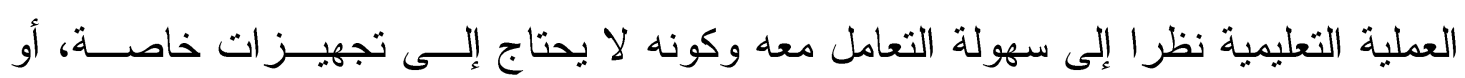

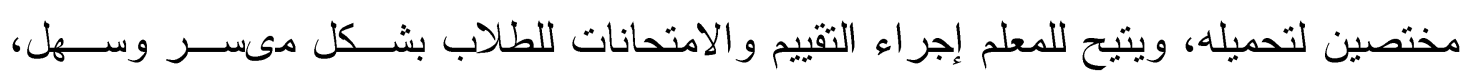

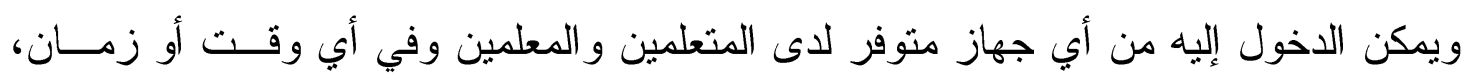

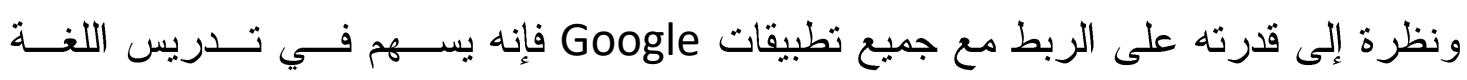

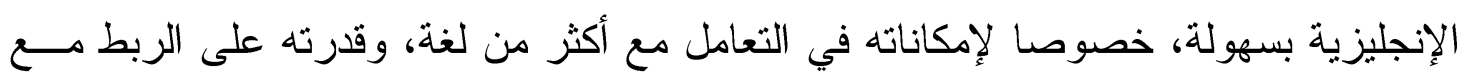
جوجل للترجمة.

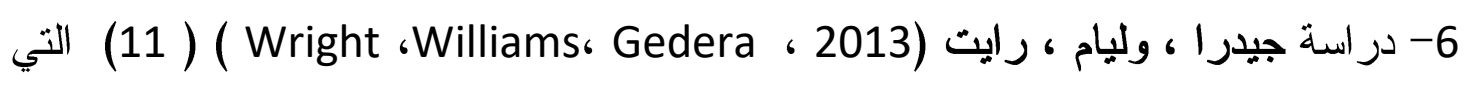

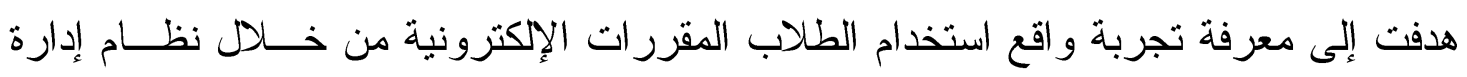
المقررات الإككترونية (Moodle) ومعرفة وجهات النظر لدى الطلاب في استخدامهم للمقرر 
من خلال النظام في إحدى الجامعات في نيوزلندا، حيث أجرى الباحثون المقابلات مع الطلاب

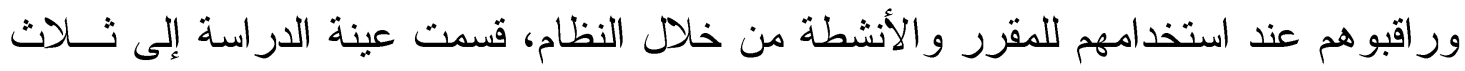

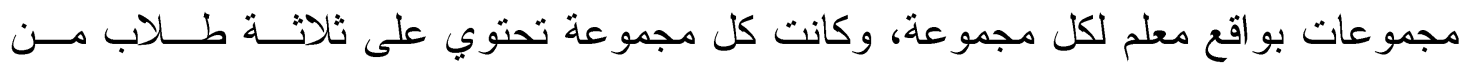

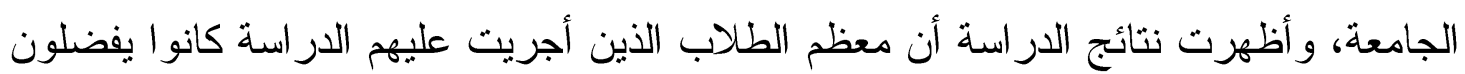

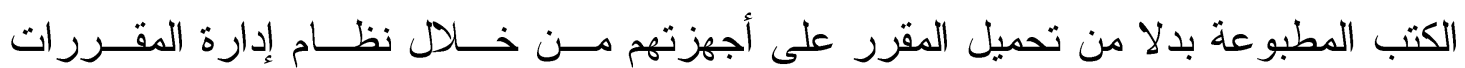
الإلكترونية (Moodle) وذلك لصعوبة تحميل المادة من الجهاز واخذ الكثير من الوقت أثتــاء

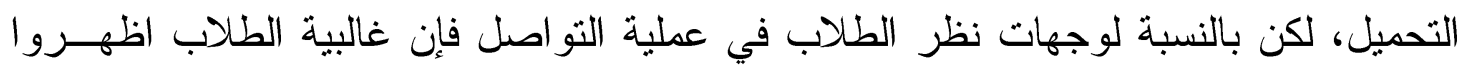
رغبتهم في عملية التواصل و المناقشات التي تتم عبر النظام.

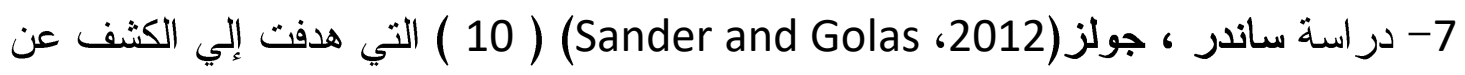
أثر استخدام المنصات التعليمية الإكترونية في تسهيل التعلم الجماعي والمشاركة في الأنشطة

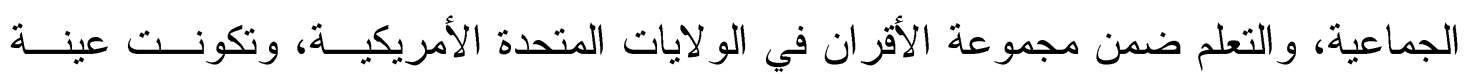

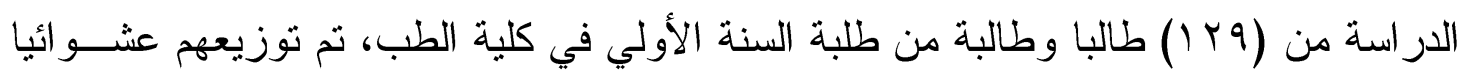

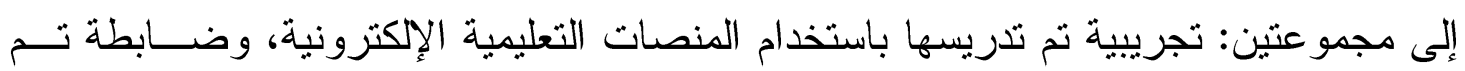

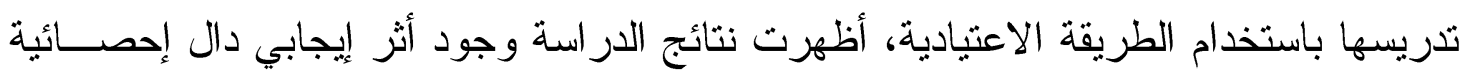

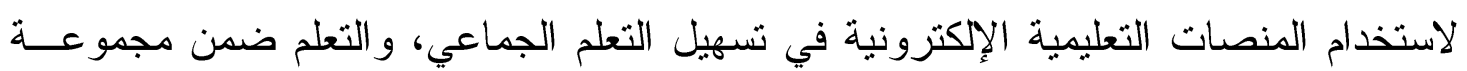

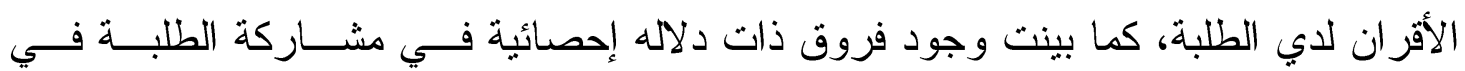

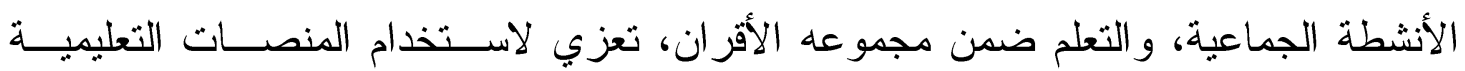
الإلكترونية لصالح المجموعة التجريبية.

$$
\text { منهج البحث: إعات البحث: }
$$

استخدم الباحث المنهج شبه التجريبي علي مجموعتين احداهما تجريبية تم التدريس لها

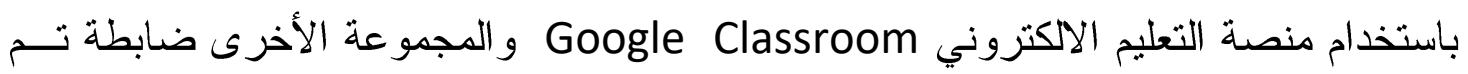

\begin{tabular}{|c|c|c|}
\hline المتغير التابع & المتغير المستقل & المجموعة المجة \\
\hline \multirow{2}{*}{ والاتجاه نحور التعلم عبر الالنترنت } & $\begin{array}{c}\text { التّريس باستخذام منصة التعليم الالكتروني } \\
\text { Google Class room }\end{array}$ & التجريبية \\
\hline & التصريس الطريقة التقليدية & الضابطة \\
\hline
\end{tabular}
التدريس لها باستخدام الطريقة التقليدية .

تمثل مجتمع البحث في جميع طلاب الفرقة الثالثة بكلية التربية الرياضية للبنين بالهرم-

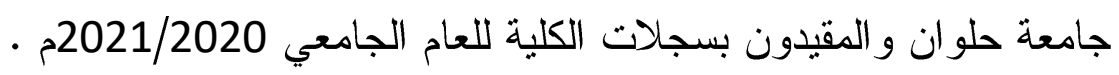


تم اختيار عينة البحث بالطريقة العمدية من طلاب التذريب الميداني الفرقة الثالثة بكلية التربية الرياضية للبنين بالهرم ، و المكلف الباحث بالإشر اف عليهم أثناء فترة التدريب الميداني و عددهم (52) طالب وتم استبعاد عدد ( 4 ) طلاب لعدم الانتظام في الحضور ، و عدد ( 10 ) طلاب لإجر اء الدر اسة الاستطلاعية عليهم، وبذلك أصبحث عينة البحث الفعلية (40) طالب مقسمين إلي ( 5 ) مجمو عات كل مجمو عة تمنل مدرسة منفصلة . توصيف عينة البحث الكلية في القياسات قيد البحث( التجانس ) : تحقق الباحث من اعتدالية توزيع أفراد عينة البحث من حيث المتغيرات قيــد البحــث، نظراً لأهمية هذه المتغير ات وتأثير ها علي التعلم، كما يتضح من جدول (1).

$$
\text { جدول ( } 1 \text { ( } 1 \text { ) }
$$

توصيف عينة البحث ككل في بطاقة ثقويم المهار ات التدريسية في التربية الرياضية ن=50

\begin{tabular}{|c|c|c|c|c|c|c|}
\hline الالتواء & المعياري & الوسيط & المتوسط الحسابي & المحور & & s \\
\hline $0.301-$ & 3.616 & 36.000 & 36.000 & مهارة التخطيط للارس & & 1 \\
\hline 0.172 & 2.246 & 19.000 & 18.675 & الجزء التمهيدي & \multirow{4}{*}{ مهارة } & \\
\hline 0.311 & 3.131 & 33.000 & 33.200 & الجزء الرئيسي ( النشاط التعليمي & & 2 \\
\hline 1.482 & 0.516 & 6.000 & 6.300 & الجزء الختامي & & \\
\hline 0.310 & 4.254 & 57.000 & 58.175 & مجموع المحور & & \\
\hline 1.062 & 1.492 & 14.000 & 13.925 & \multicolumn{2}{|l|}{ مهارة تقويم الدرس } & 3 \\
\hline 0.015 & 6.574 & 108.000 & 108.100 & \multicolumn{2}{|l|}{ مجموع البطاقة } & \\
\hline
\end{tabular}

تشير نتائج جدول ( 1 ) إلى المتوسط الحسابي و الانحر اف المعياري و الوسيط ومعامل الالتو اء لأبعاد ومحاور و المجموع الكلي لبطاقة تقويم المهار ات التذريسية في التربية الرياضبة في القياس القبلي، كما يتضح من الجدول اعتدالية توزيع أفراد العينة فـي ابعــاد ومحسـاور ومجموع بطاقة تقويم المهار ات التدريسية في التربية الرياضية حيث تراوح معامل الالتــواء

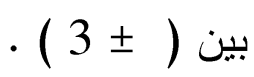

$$
\text { جدول ( } 2 \text { ) }
$$

\begin{tabular}{|c|c|c|c|c|}
\hline معامل الألتواء & الإنحراف المعيارى & الوسياط & المتوسط الحسابي & المقياس \\
\hline 0.722 & 6.669 & 122.500 & 122.300 & التعمو القائم على الإنترنت نحو \\
\hline
\end{tabular}

توصيف عينة البحث ككل في مقياس الاتجاه نحو التعلم القائم على الإنترنت ن=50

تشير نتائج جدول ( 2 ) إلى المتوسط الحسابي و الانحر اف المعياري و الوسيط ومعامل

الالتواء للمجموع الكلي لمقياس الاتجاه نحو التعلم القائم على الإنترنت في القياس القبلي، كما 


\section{المجلة العلمية للثربية البدنية وعلوم الرياضة العدد (93) الجزء (1)}

يتضح من الجدول اعتدالية توزيع أفراد العينة في مجموع مقياس الاتجاه نحو التعلم القائم على التى

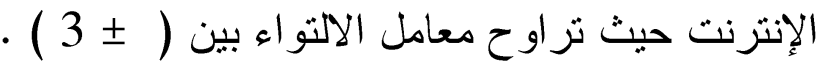

$$
\begin{aligned}
& \text { وسائل وأدوات جمع البيانات : }
\end{aligned}
$$

قام الباحث بالاطلاع على المر اجع و الدراسات السابقة المشابهة بغرض الاستفادة منها

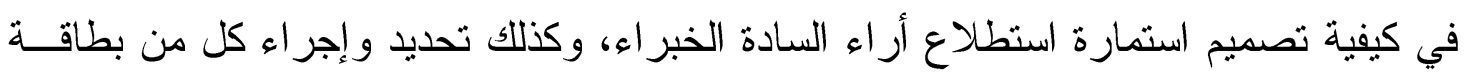
التقويم الذاتي، ومقياس الاتجاه .

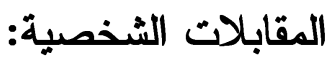

قام الباحث بإجر اء بعض المقابلات الشخصية مع اساتذة المناهج وطرق التدريس بكليات

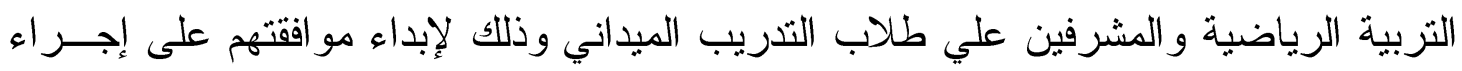

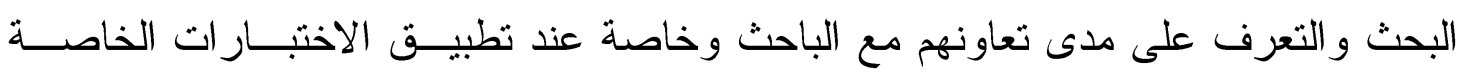

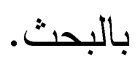

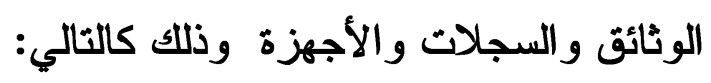

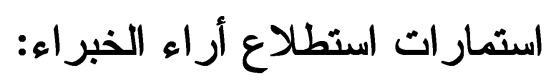

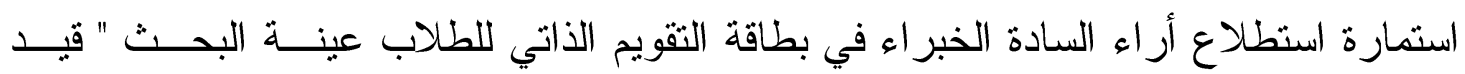
البحث". مرفق ( 1 ) استمارة استطلاع أراء السادة الخبراء في مقياس الاتجاه نحو التعلم القائم على الإنترنت " قبد

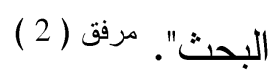

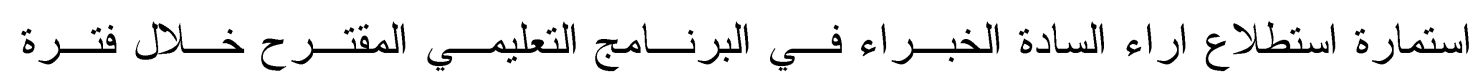

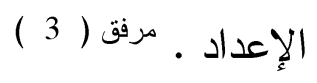
الاختبار ات و المقاييس المستخدمة:

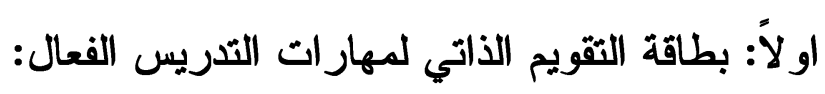

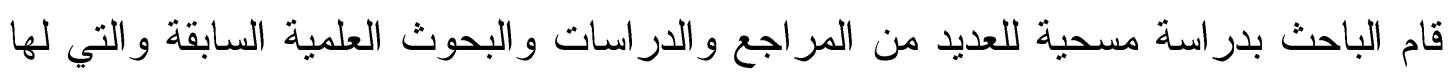

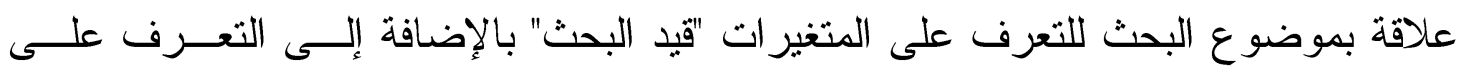

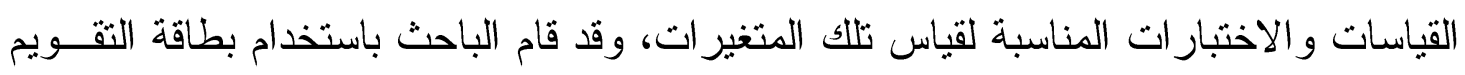

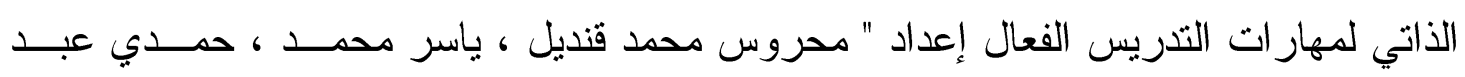
الفتاح ( 2015 ) ) ثانياً : مقياس الاتجاه نحو التعلم عبر الانترنت :

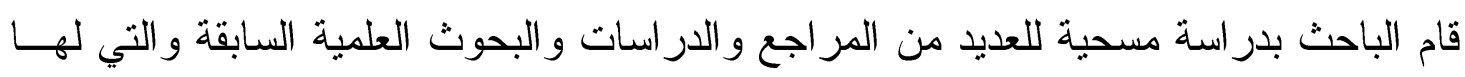
علاقة بموضوع البحث للتعرف على المتغير ات "قيد البحث" وقد استخدم الباحث مقياس الاتجاه 
نحو التعلم القائم علي الانترنت الذي سبق وقام بإعداده حسن الباتع محمد عبد العاطي ( 2006

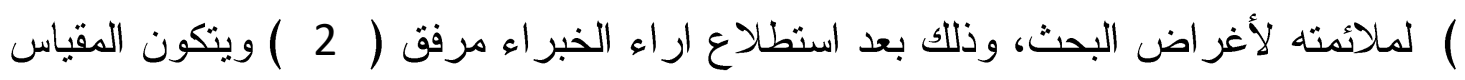

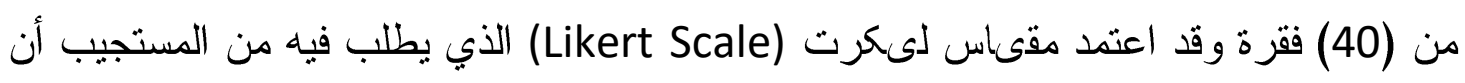

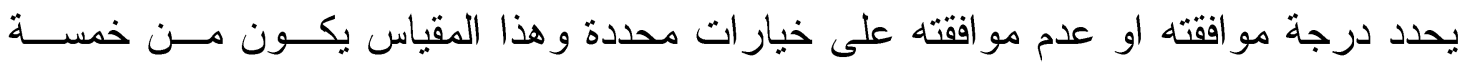

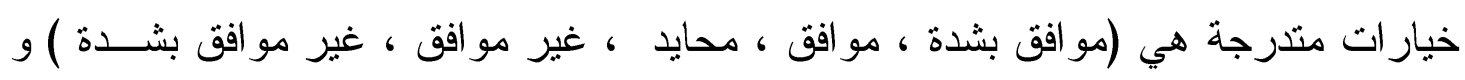

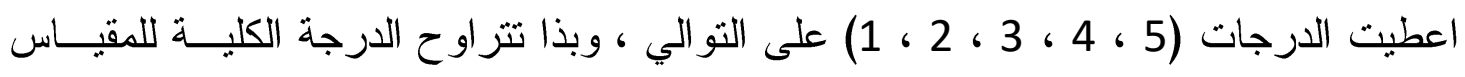
(من 40 الى 200) وللتحقق من صدق المقياس لأن صدق المقياس من الخصائص المهمة التي

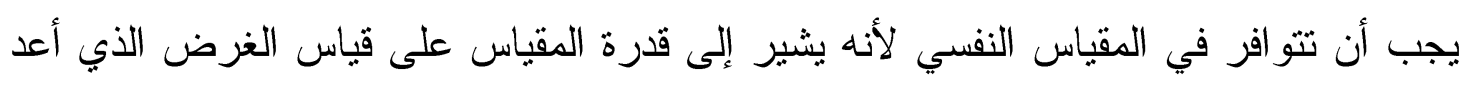

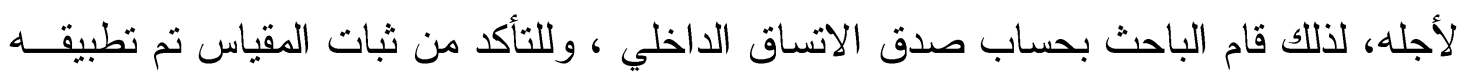

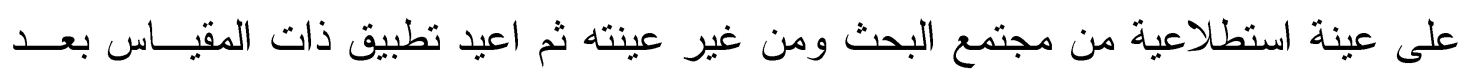

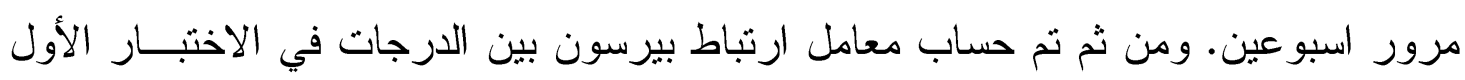

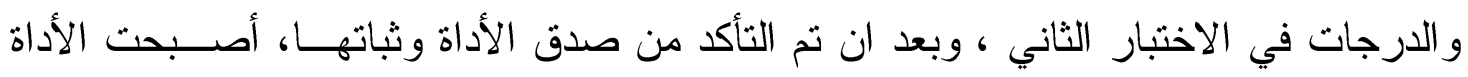
جاهزة للتطبيق.

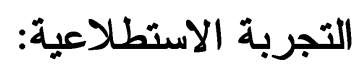

قام الباحث بإجر اء التجربة الاستطلاعية على عينة من طلاب الفرقة الثالثــة بكليــة

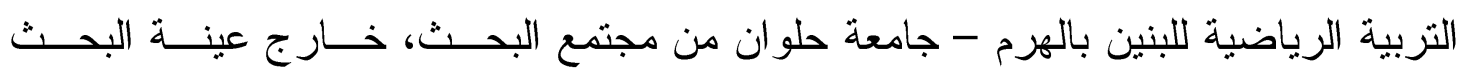

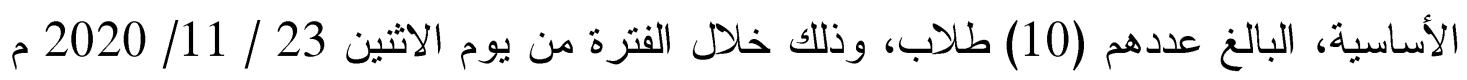
إلى يوم الاثثين 2020/12/7 م بهدف تطبيق المتغيرات قيد البحث بعد إجراء التعـديلات

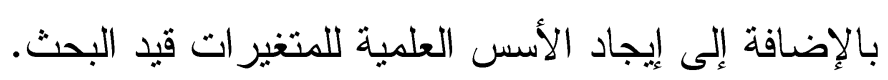

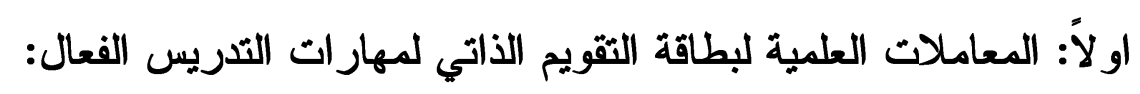

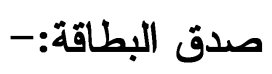

تحقق الباحث من صدق الاختبار ات المستخدمة عن طريق :

صدق المحمين ( المحتوى ) :

عرض استمارة استطلاع رأي تحتوي على جميع الاختبار ات السابقة قبل استخدامها بهذا البحث على الخبر اء لتحديد مدى صدقها في قياس ما وضعت من أجله وقد اتفقو العلى مناسبتها

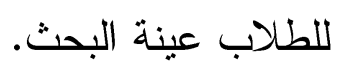

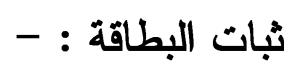

تم حساب معامل الثبات عن طريق تطبيق الاختبار و إعادة تطبيقه على تلاميــذ عينـــة

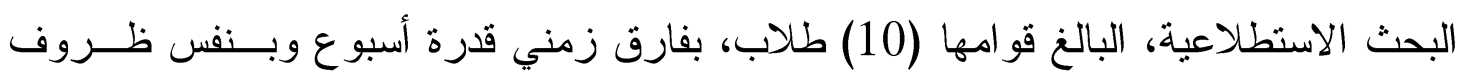


التطبيق الأول، و إيجاد معامل الارتباط بين التطبيقين، كما يتضح من جدول ( 3 )

$$
\text { جدول ( } 3 \text { ( ) }
$$

قيم معامل الارتباط بين التطبيق و إعادة التطبيق لعبار ات بطاقة تقويم المهار ات التنريسية في

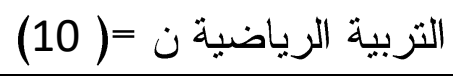

\begin{tabular}{|c|c|c|c|c|c|c|c|c|c|c|c|}
\hline \multirow[b]{2}{*}{ الارتباط معل } & \multicolumn{2}{|c|}{ إعادة التطبيق } & \multicolumn{2}{|c|}{ التطبيق } & \multirow[b]{2}{*}{ العبارة } & \multirow[b]{2}{*}{ معامل } & \multicolumn{2}{|c|}{ إعادة التطبيق } & \multicolumn{2}{|c|}{ التطبيق } & \multirow[b]{2}{*}{ 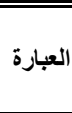 } \\
\hline & الالنحراف & المستوسط & الالحعراف & المتوسطي & & & الانحراف & الحستوسي & الالحعراف & الحستوسطي & \\
\hline *0.709 & 0.483 & 1.300 & 0.483 & 1.300 & 3 & \multicolumn{6}{|c|}{ المحور الأول "مهارة التخطيط للارس" } \\
\hline$* 0.775$ & 0.316 & 1.100 & 0.316 & 1.100 & 4 & $* 0.656$ & 0.422 & 1.200 & 0.316 & 1.100 & 1 \\
\hline *0.727 & 0.483 & 1.300 & 0.422 & 1.200 & 5 & $* 0.700$ & 0.675 & 1.300 & 0.527 & 1.500 & 2 \\
\hline$* 0.800$ & 0.422 & 1.200 & 0.422 & 1.200 & 6 & $* 0.701$ & 0.422 & 1.200 & 0.316 & 1.100 & 3 \\
\hline$* 0.811$ & 0.789 & 1.800 & 0.483 & 1.300 & 7 & $* 0.664$ & 0.699 & 1.400 & 0.675 & 1.300 & 4 \\
\hline$* 0.718$ & 0.422 & 1.200 & 0.422 & 1.200 & 8 & $* 0.633$ & 0.516 & 1.400 & 0.316 & 1.100 & 5 \\
\hline$* 0.750$ & 0.527 & 1.500 & 0.316 & 1.100 & 9 & $* 0.666$ & 0.527 & 1.500 & 0.699 & 1.400 & 6 \\
\hline$* 0.750$ & 0.316 & 1.100 & 0.483 & 1.300 & 10 & $* 0.675$ & 0.483 & 1.300 & 0.422 & 1.200 & 7 \\
\hline$* 0.748$ & 0.527 & 1.500 & 0.422 & 1.200 & 11 & $* 0.711$ & 0.699 & 1.600 & 0.316 & 1.100 & 8 \\
\hline$* 0.811$ & 0.422 & 1.200 & 0.422 & 1.200 & 12 & $* 0.702$ & 0.316 & 1.100 & 0.699 & 1.400 & 9 \\
\hline$* 0.811$ & 0.422 & 1.200 & 0.632 & 1.200 & 13 & $* 0.708$ & 0.422 & 1.200 & 0.422 & 1.200 & 10 \\
\hline$* 0.800$ & 0.707 & 1.500 & 0.316 & 1.100 & 14 & $* 0.659$ & 0.843 & 1.600 & 0.316 & 1.100 & 11 \\
\hline *0.818 & 0.316 & 1.100 & 0.316 & 1.100 & 15 & $* 0.675$ & 0.516 & 1.400 & 0.843 & 1.600 & 12 \\
\hline$* 0.818$ & 0.316 & 1.100 & 0.843 & 1.400 & 16 & $* 0.767$ & 0.707 & 1.500 & 0.422 & 1.200 & 13 \\
\hline *0.795 & 0.527 & 1.500 & 0.422 & 1.200 & 17 & $* 0.636$ & 0.422 & 1.200 & 0.422 & 1.200 & 14 \\
\hline$* 0.767$ & 0.483 & 1.300 & 0.316 & 1.100 & 18 & $* 0.675$ & 0.316 & 1.100 & 0.699 & 1.400 & 15 \\
\hline$* 0.767$ & 0.483 & 1.300 & 0.699 & 1.400 & 19 & $* 0.802$ & 0.699 & 1.400 & 0.422 & 1.200 & 16 \\
\hline *0.707 & 0.483 & 1.300 & 0.316 & 1.100 & 20 & $* 0.675$ & 0.422 & 1.200 & 0.843 & 1.400 & 17 \\
\hline$* 0.767$ & 0.422 & 1.200 & 0.316 & 1.100 & 21 & $* 0.634$ & 0.516 & 1.400 & 0.422 & 1.200 & 18 \\
\hline$* 0.767$ & 0.422 & 1.200 & 0.675 & 1.300 & 22 & $* 0.710$ & 0.422 & 1.200 & 0.422 & 1.200 & 19 \\
\hline *0.789 & 0.483 & 1.300 & 0.632 & 1.200 & 23 & $* 0.777$ & 0.675 & 1.300 & 0.850 & 1.500 & 20 \\
\hline$* 0.999$ & 0.422 & 1.200 & 0.422 & 1.200 & 24 & $* 0.667$ & 0.422 & 1.200 & 0.316 & 1.100 & 21 \\
\hline *0.911 & 0.316 & 1.100 & 0.516 & 1.400 & 25 & $* 0.567$ & 0.422 & 1.200 & 0.316 & 1.100 & 22 \\
\hline$* 0.734$ & 0.483 & 1.300 & 0.422 & 1.200 & 26 & $* 0.667$ & 0.422 & 1.200 & 0.632 & 1.200 & 23 \\
\hline *0.796 & 0.527 & 1.500 & 0.632 & 1.200 & 27 & $* 0.672$ & 0.843 & 1.400 & 0.422 & 1.200 & 24 \\
\hline$* 0.767$ & 0.316 & 1.100 & 0.422 & 1.200 & 28 & $* 0.667$ & 0.316 & 1.100 & 0.316 & 1.100 & 25 \\
\hline *0.767 & 3.315 & 35.900 & 4.067 & 34.100 & مج ب & $* 0.875$ & 0.516 & 1.400 & 0.422 & 1.200 & 26 \\
\hline \multicolumn{6}{|c|}{ البعد الثالث "الجزء الختامي" } & $* 0.718$ & 0.316 & 1.100 & 0.422 & 1.200 & 27 \\
\hline$* 0.867$ & 0.483 & 1.300 & 0.316 & 1.100 & 1 & $* 0.652$ & 0.422 & 1.200 & 0.483 & 1.300 & 28 \\
\hline$* 0.772$ & 0.422 & 1.200 & 0.316 & 1.100 & 2 & $* 0.709$ & 0.422 & 1.200 & 0.422 & 1.200 & 29 \\
\hline$* 0.808$ & 0.422 & 1.200 & 0.316 & 1.100 & 3 & $* 0.667$ & 3.472 & 37.500 & 2.789 & 36.000 & $\begin{array}{l}\text { مج } \\
1\end{array}$ \\
\hline$* 0.818$ & 0.422 & 1.200 & 0.316 & 1.100 & 4 & \multicolumn{6}{|c|}{ المحور الثاني "مهارة تنفيذ الدرس" } \\
\hline$* 0.870$ & 0.516 & 1.400 & 0.516 & 1.400 & 5 & \multicolumn{6}{|c|}{ البعد الأول "الجزء التمهيدي" } \\
\hline$* 0.710$ & 0.316 & 1.100 & 0.316 & 1.100 & 6 & $* 0.718$ & 0.516 & 1.400 & 0.316 & 1.100 & 1 \\
\hline$* 0.748$ & 0.966 & 7.400 & 0.876 & 6.900 & 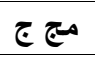 & $* 0.711$ & 0.422 & 1.200 & 0.422 & 1.200 & 2 \\
\hline$* 0.750$ & 4.625 & 63.500 & 5.195 & 59.100 & مج 2 & $* 0.733$ & 0.483 & 1.300 & 0.316 & 1.100 & 3 \\
\hline
\end{tabular}




\section{المجلة العلمية التربية البدنية وعلوم الرياضة العدد (93) الجزء (1)}

سبتمبر 2021

\begin{tabular}{|c|c|c|c|c|c|c|c|c|c|c|c|}
\hline \multicolumn{6}{|c|}{ المحور الثالث "مهارة تقويم الدرس" } & *0.667 & 0.316 & 1.100 & 0.316 & 1.100 & 4 \\
\hline$* 0.767$ & 0.316 & 1.100 & 0.707 & 1.500 & 1 & $* 0.656$ & 0.527 & 1.500 & 0.422 & 1.200 & 5 \\
\hline$* 0.833$ & 0.316 & 1.100 & 0.422 & 1.200 & 2 & $* 0.808$ & 0.316 & 1.100 & 0.483 & 1.300 & 6 \\
\hline$* 0.875$ & 0.422 & 1.200 & 0.422 & 1.200 & 3 & $* 0.818$ & 0.516 & 1.600 & 0.422 & 1.200 & 7 \\
\hline$* 0.810$ & 0.316 & 1.100 & 0.527 & 1.500 & 4 & $* 0.818$ & 0.516 & 1.400 & 0.316 & 1.100 & 8 \\
\hline *0.709 & 0.316 & 1.100 & 0.675 & 1.300 & 5 & $* 0.775$ & 0.483 & 1.300 & 0.483 & 1.300 & 9 \\
\hline$* 0.750$ & 0.483 & 1.300 & 0.850 & 1.500 & 6 & $* 0.802$ & 0.843 & 1.600 & 0.422 & 1.200 & 10 \\
\hline$* 0.727$ & 0.422 & 1.200 & 0.483 & 1.300 & 7 & $* 0.664$ & 0.422 & 1.200 & 0.422 & 1.200 & 11 \\
\hline$* 0.818$ & 0.316 & 1.100 & 0.422 & 1.200 & 8 & $* 0.807$ & 0.516 & 1.400 & 0.516 & 1.400 & 12 \\
\hline$* 0.850$ & 0.422 & 1.200 & 0.422 & 1.200 & 9 & *0.806 & 0.675 & 1.300 & 0.483 & 1.300 & 13 \\
\hline *0.999 & 0.483 & 1.300 & 0.483 & 1.300 & 10 & $* 0.745$ & 0.675 & 1.300 & 0.483 & 1.300 & 14 \\
\hline *0.969 & 0.316 & 1.100 & 0.422 & 1.200 & 11 & $* 0.824$ & 0.850 & 1.500 & 0.316 & 1.100 & 15 \\
\hline$* 0.667$ & 0.422 & 1.200 & 0.516 & 1.400 & 12 & $* 0.889$ & 1.549 & 20.200 & 2.234 & 18.100 & مج أ \\
\hline *0.804 & 0.943 & 14.000 & 2.251 & 15.800 & مج 3 & \multicolumn{6}{|c|}{ البعد الثاني "النشاط التعليمي و التطبيقي" } \\
\hline$* 0.875$ & 6.146 & $\begin{array}{c}115.00 \\
0\end{array}$ & 7.203 & 110.900 & مج الكل & $* 0.827$ & 0.422 & 1.200 & 0.516 & 1.400 & 1 \\
\hline & & & & & & $* 0.718$ & 0.483 & 1.300 & 0.422 & 1.200 & 2 \\
\hline
\end{tabular}

* قيمة " ر " الجدولية عند مستوى معنوية 0.05 هى 0.632

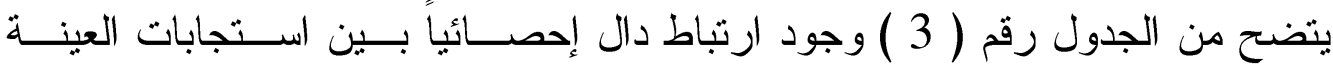

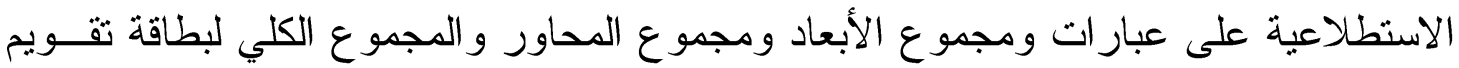

المهارات التدريسية في التربية الرياضية في التطبيق و إعادة التطبيق مما يدل على درجة ثبات

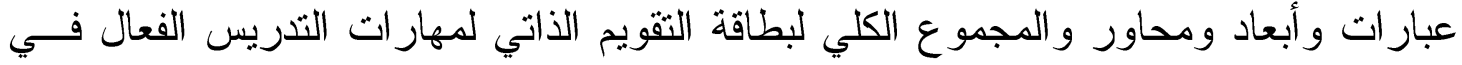
التربية الرياضية.

ثانياً : المعاملات العلمية لمقياس الاتجاه نحو التعلم عبر الانترنت : استخدم الباحث نوعان لحساب الصدق كالتالي:صدق المحكمين ( المحتوى ) :

تحقق الباحث من صدق الاختبار ات المستخدمة عن طريق :

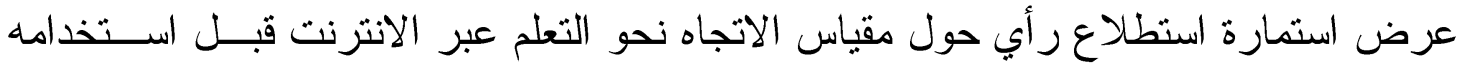

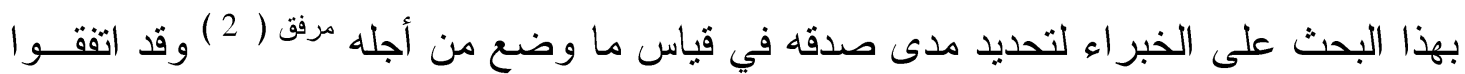
على مناسبتها بنسبة (90\%) للعينة "قيد البحث". ب/ بدق الاتساق الداخلي:

تحقق الباحث من صدق الاتساق الداخلي لمقياس الاتجاه نحو التعلم القائم على الإنترنت عـن طريق تطبيقه على عينة قو امها (10) طلاب من طلاب الفرقة الثالثة بكلية التربية الرياضـــية

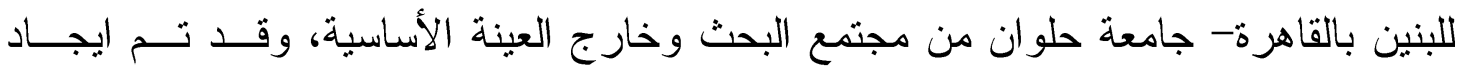
الارتباط الثنائي بين درجة كل عبارة و الدرجة الكلية للبعد الذي تنتمي إليه ، كما يتضح مستهن 


\section{المجلة العمية للتربية البدنية وعلوم الرياضة العدد (93) الجزء (1)}

$$
\text { جدول ( } 4 \text { ( ) }
$$

صدق الاتساق الداخلي لعبار ات مقياس الاتجاه نحو التعلم القائم على الإنترنت ن =( 10 )

\begin{tabular}{|c|c|c|c|c|c|c|c|c|c|c|c|}
\hline الارتباط & المعيارى & الحسابى & العبارة & معامل الارتباط & المعيارى & الحسابى & العبارة & الارتباط & المعيارى & الحسابى & العبار \\
\hline 0.420 & 0.699 & 1.600 & 29 & 0.347 & 0.823 & 2.300 & 15 & 0.292 & 0.789 & 2.200 & 1 \\
\hline 0.144 & 0.994 & 3.900 & 30 & 0.299 & 0.876 & 3.900 & 16 & -0.389 & 0.816 & 2.000 & 2 \\
\hline 0.147 & 1.354 & 2.500 & 31 & 0.405 & 1.059 & 2.700 & 17 & -0.302 & 1.370 & 3.900 & 3 \\
\hline 0.423 & 0.994 & 3.900 & 32 & -0.193 & 0.699 & 4.400 & 18 & 0.436 & 0.876 & 1.900 & 4 \\
\hline 0.293 & 1.059 & 2.700 & 33 & 0.477 & 0.483 & 1.700 & 19 & -0.446 & 1.247 & 4.000 & 5 \\
\hline-0.088 & 1.354 & 3.500 & 34 & 0.327 & 0.972 & 4.500 & 20 & 0.224 & 0.994 & 1.900 & 6 \\
\hline 0.151 & 1.054 & 3.000 & 35 & 0.191 & 1.247 & 2.000 & 21 & -0.396 & 0.422 & 2.200 & 7 \\
\hline-0.526 & 0.876 & 4.100 & 36 & -0.385 & 0.949 & 3.700 & 22 & 0.428 & 1.449 & 3.900 & 8 \\
\hline-0.238 & 1.135 & 2.800 & 37 & 0.073 & 0.876 & 1.900 & 23 & 0.506 & 0.943 & 2.000 & 9 \\
\hline-0.251 & 0.823 & 3.700 & 38 & 0.112 & 0.707 & 3.500 & 24 & -0.032 & 0.738 & 2.100 & 10 \\
\hline-0.263 & 0.483 & 2.700 & 39 & -0.176 & 1.265 & 2.600 & 25 & -0.091 & 0.699 & 3.600 & 11 \\
\hline \multirow[t]{2}{*}{0.138} & 0.919 & 3.800 & 40 & 0.304 & 0.994 & 3.900 & 26 & -0.296 & 1.663 & 3.900 & 12 \\
\hline & 2.797 & 120.600 & مج & 0.165 & 0.675 & 1.700 & 27 & 0.225 & 1.414 & 2.000 & 13 \\
\hline & & & & 0.294 & 0.919 & 4.200 & 28 & 0.268 & 0.919 & 3.800 & 14 \\
\hline
\end{tabular}

"قيمة "ر" الجدولية عند مستوى معنوية 0.05 هي 0.349

تشير نتائج الجدول ( 4 ) إلى أنه توجد علاقة ارتباطية ذات دلاله إحصـائية بـين

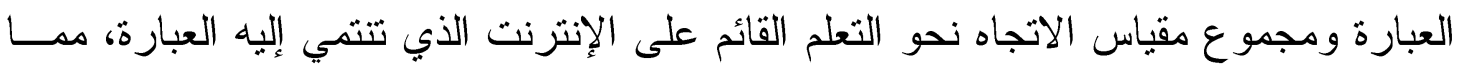
يدل على صدق عبار ات مقياس الاتجاه نحو التعلم القائم على الإنترنت.

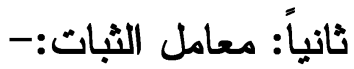

تم حساب معامل الثبات بطريقة تطبيق الاختبار ات و إعادة تطبيقه Test, Retest، على عينة

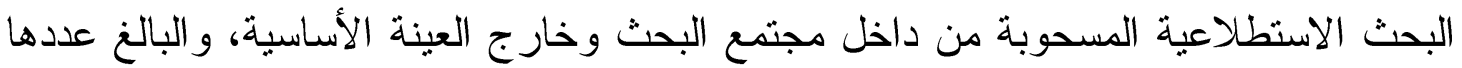

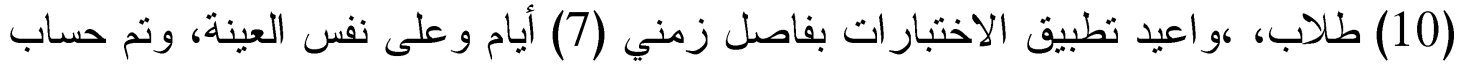
معامل الارتباط بين التطبيقين كدلالة لمعامل الثبات و الاستثرار باســتخدام قــانون الارتبــاط البسيط (بيرسون)، كما يتضح من جدول ( 5 (الرئ ). 


\section{المجلة العلمية للتربية البدنية وعلوم الرياضة العدد (93) الجزء (1)}

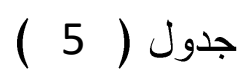

قيم دعامل الارتباط بين التطبيق و إعادة التطبيق لعبار ات مقياس الاتجاه نحو التعلم القائم على

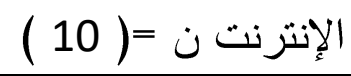

\begin{tabular}{|c|c|c|c|c|c|c|c|c|c|c|c|}
\hline \multirow{2}{*}{ الارتباط } & \multicolumn{2}{|c|}{ إعادة التطبيق } & \multicolumn{2}{|c|}{ التطبيق } & \multirow{2}{*}{ العبارة } & \multirow{2}{*}{ الارتباط } & \multicolumn{2}{|c|}{ إعادة التطبيق } & \multicolumn{2}{|c|}{ التطبيق } & \multirow{2}{*}{ العبارة } \\
\hline & المعيارى & الحستوسط & المعيارى & الحستوسط & & & الالاتحراف & الحستوسطى & المعيارى & الحستوسي & \\
\hline *0.937 & 0.789 & 4.200 & 0.949 & 3.700 & 22 & ${ }^{*} 0.688$ & 0.823 & 2.300 & 0.789 & 2.200 & 1 \\
\hline$* 0.844$ & 0.789 & 2.200 & 0.876 & 1.900 & 23 & $* 0.721$ & 0.876 & 2.100 & 0.816 & 2.000 & 2 \\
\hline$* 0.724$ & 0.876 & 3.900 & 0.707 & 3.500 & 24 & $* 0.663$ & 0.823 & 3.700 & 1.370 & 3.900 & 3 \\
\hline$* 0.712$ & 1.075 & 2.400 & 1.265 & 2.600 & 25 & $* 0.700$ & 0.843 & 2.400 & 0.876 & 1.900 & 4 \\
\hline$* 0.833$ & 0.789 & 4.200 & 0.994 & 3.900 & 26 & $* 0.889$ & 0.823 & 3.300 & 1.247 & 4.000 & 5 \\
\hline$* 0.641$ & 0.876 & 1.900 & 0.675 & 1.700 & 27 & $* 0.705$ & 0.994 & 2.100 & 0.994 & 1.900 & 6 \\
\hline *0.855 & 0.738 & 4.100 & 0.919 & 4.200 & 28 & $* 0.821$ & 0.632 & 1.800 & 0.422 & 2.200 & 7 \\
\hline *0.944 & 0.699 & 1.600 & 0.699 & 1.600 & 29 & $* 0.652$ & 1.252 & 3.700 & 1.449 & 3.900 & 8 \\
\hline$* 0.533$ & 0.816 & 4.000 & 0.994 & 3.900 & 30 & $* 0.706$ & 0.876 & 2.100 & 0.943 & 2.000 & 9 \\
\hline *0.651 & 1.418 & 2.300 & 1.354 & 2.500 & 31 & $* 0.717$ & 0.789 & 2.200 & 0.738 & 2.100 & 10 \\
\hline$* 0.663$ & 0.876 & 4.100 & 0.994 & 3.900 & 32 & $* 0.640$ & 0.699 & 3.600 & 0.699 & 3.600 & 11 \\
\hline *0.758 & 1.269 & 2.500 & 1.059 & 2.700 & 33 & $* 0.823$ & 1.370 & 4.100 & 1.663 & 3.900 & 12 \\
\hline$* 0.742$ & 1.229 & 3.800 & 1.354 & 3.500 & 34 & $* 0.940$ & 1.252 & 2.300 & 1.414 & 2.000 & 13 \\
\hline *0.871 & 1.135 & 3.200 & 1.054 & 3.000 & 35 & $* 0.672$ & 1.059 & 3.700 & 0.919 & 3.800 & 14 \\
\hline *0.741 & 0.789 & 4.200 & 0.876 & 4.100 & 36 & $* 0.685$ & 0.632 & 2.200 & 0.823 & 2.300 & 15 \\
\hline *0.881 & 1.197 & 2.900 & 1.135 & 2.800 & 37 & $* 0.919$ & 0.667 & 4.000 & 0.876 & 3.900 & 16 \\
\hline *0.798 & 0.823 & 3.700 & 0.823 & 3.700 & 38 & $* 0.690$ & 1.317 & 1.800 & 1.059 & 2.700 & 17 \\
\hline$* 0.940$ & 0.943 & 2.000 & 0.483 & 2.700 & 39 & $* 0.821$ & 0.568 & 4.100 & 0.699 & 4.400 & 18 \\
\hline *0.905 & 0.789 & 3.800 & 0.919 & 3.800 & 40 & *0.887 & 0.789 & 2.200 & 0.483 & 1.700 & 19 \\
\hline$* 0.849$ & 4.397 & 121.000 & 2.797 & 120.600 & مج & $* 0.775$ & 0.949 & 4.300 & 0.972 & 4.500 & 20 \\
\hline & & & & & & ${ }^{*} 0.653$ & 0.943 & 2.000 & 1.247 & 2.000 & 21 \\
\hline
\end{tabular}

* قيمة " ر " الجدولية عند مستوى معنوية 0.05 هي 0.632

يتضح من الجدول رقم ( 5 ) إلى أنه يوجد ارتباط دال إحصائياً بين استجابات العينة

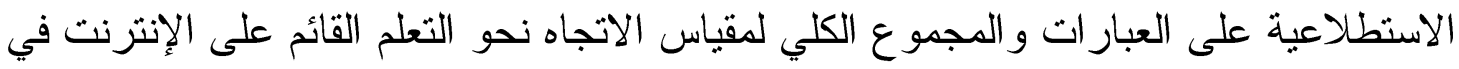

النطبيق و إعادة النطبيق مما يدل على درجة ثبات العبارات و المجموع الكلي لمقياس الاتجـــــاه

$$
\text { نحو التعلم القائم على الإنترنت. }
$$

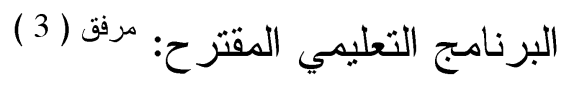

إعداد منصة التعليم الأكتروني Google Class room

تم اختيار المنصة التعليمية Google Class room لأنها منصة حديثة في مجال التـدريس ،

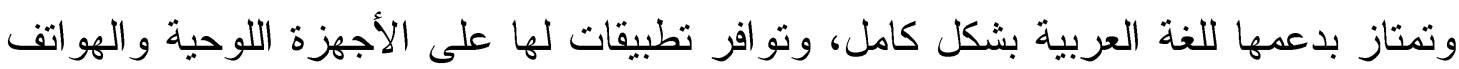

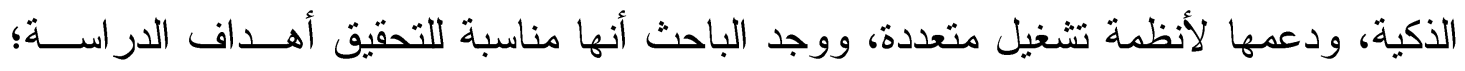

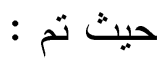


تسجيل حساب في المنصة التعليمية، و اعداد صف إلكتروني.

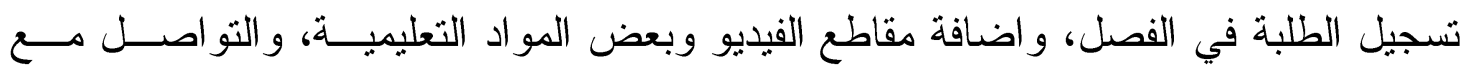

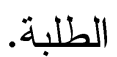

اعداد الخطط التّريسية للمجموعة التجريبية و الهجموعة الضابطة.

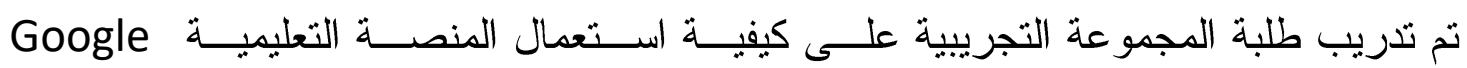
Classroom ، قبل التدريس الفعلي. درست المجموعة التجريبية وفق المنصة التعليمية Google Classroom وكــان تطبيـق التجربة على جزأين : التهن الجزء الأول: خارج المدرسة ، فتم التتبيه على الطلبة بالتسجيل في المنصة التعليمية باستخدام

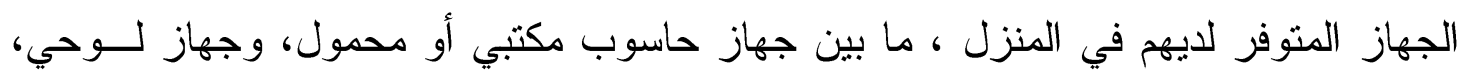

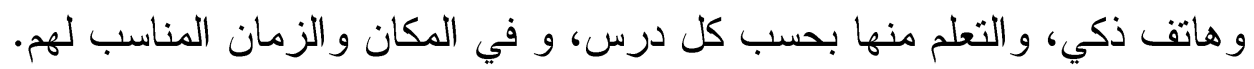

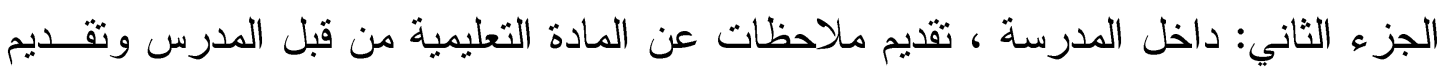

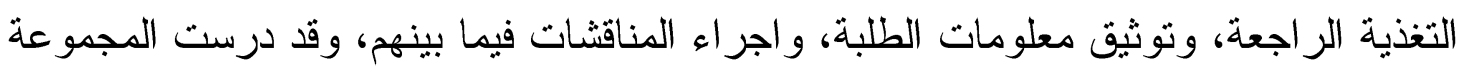

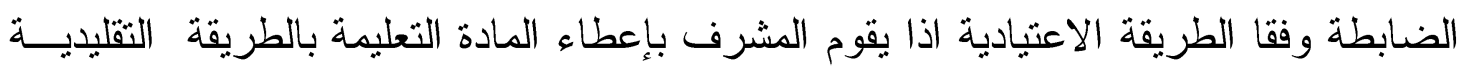
و وامتدث التجربة على مدى عام در اسي كامل. وبعد الانتهاء من فترة التدريب الميداني .

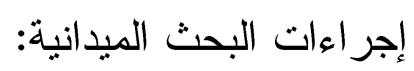

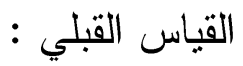

قام الباحث بإجر اء القياس القبلي للمجموعتين التجريبية و الضابطة في المتغيرات "قيد

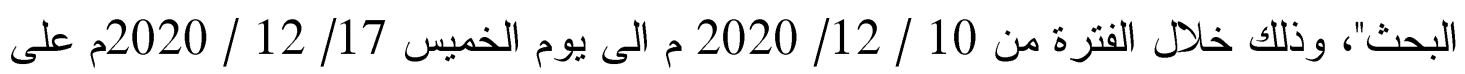

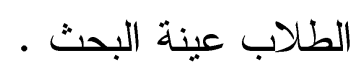
خطوات تتفيذ البرنامج النحليمي المقترح :

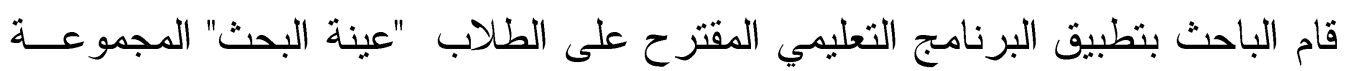

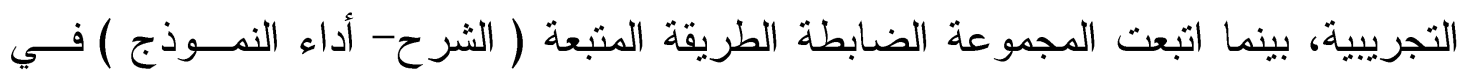
التدريس وذلك عقب القياس القبلي وفي خلال الفترة من يوم الخميس 12/24 / 2020 م م الى لى يوم 6/ 4/ 2021 م بو اقع (12) وحدة تعليمية .

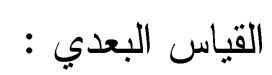

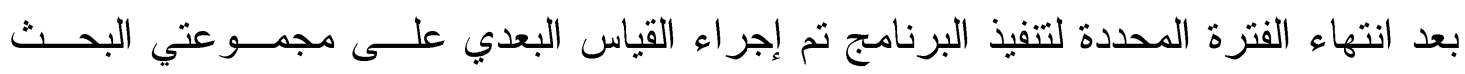

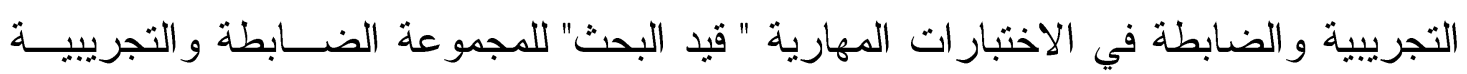
خلال الفترة من يوم الخميس 8 / 4 / 2021 م الى يوم الخميس 15 /4 / 2021 م م ، وقد تم 


\section{المجلة العلمية للثربية البدنية وعلوم الرياضة العدد (93) الجزء (1)}

القياس للاختبار ات المهارية على نحو ما تم إجراؤه في القياس القبلي .

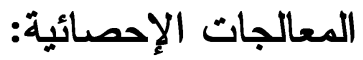
استخدم الباحث المعالجات الإحصائية للبيانات الأساسية داخل هذا البحث باســتخدام برنــامج الحزمة الإحصائية للعلوم الاجتماعية : .(Statistical Package for Social Science (SPSS )

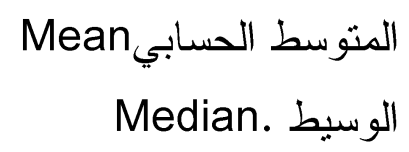
الانحر اف المعياري.Standard Deviation Skewness. معامل الالتو الاء

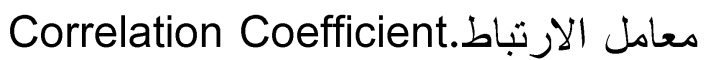

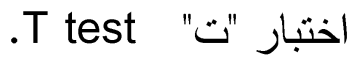
عرض ومناقشة وتفسير النتائج:

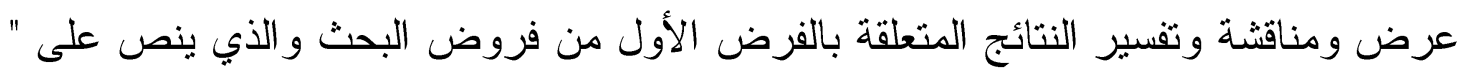
يوجد فروق ذات دلالة إحصائية عند مستوى الدلالة بين منوسط المهارات التدريسية لــدي الطلاب الذين يدرسون باستخدام المنصة التعليمية Google Classroom ومنوسط المهــار ات التدريسية للطلاب الذين يدرسون على وفق الطريقة التقليدية ، وللتحقق من صحة الفرضية نم استخدام اختبار (T-TEST) لدلالة الفروق بين القياسات القبلية و البعدية للمجموعة الضابطة، كما يتضح من جدول ( 6 ( ).

$$
\text { جدول ( } 6 \text { ) }
$$

دلاله الفروق بين المجموعة التجريبية و المجموعة الضابطة في بطاقة تقويم المهارات التدريسية في التربية الرياضية في القياس القبلي

\begin{tabular}{|c|c|c|c|c|c|c|c|}
\hline احتمال الخطأ & قيمة " ذ & مجموع الرتب & متوسط الرتب & 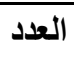 & المجموعة & المحور & \\
\hline \multirow{2}{*}{0.431} & \multirow{2}{*}{0.788} & 381.00 & 19.05 & 20 & التجريبية & \multirow{2}{*}{\multicolumn{2}{|c|}{ مهارة التخطيط للارس }} \\
\hline & & 439.00 & 21.95 & 20 & الضابطة & & \\
\hline \multirow{2}{*}{0.352} & \multirow{2}{*}{0.931} & 376.00 & 18.80 & 20 & التجريبية & \multirow{2}{*}{ الجزء التمهيدي } & \multirow{8}{*}{ تلفهارة } \\
\hline & & 444.00 & 22.20 & 20 & الضابطة & & \\
\hline \multirow{2}{*}{0.368} & \multirow{2}{*}{0.900} & 377.00 & 18.85 & 20 & التجريبية & \multirow{2}{*}{ الجزء الرئيسي ( النشياط } & \\
\hline & & 443.00 & 22.15 & 20 & الضابطة & & \\
\hline \multirow{2}{*}{0.265} & \multirow{2}{*}{1.114} & 442.00 & 22.10 & 20 & التجريبية & \multirow{2}{*}{ الجزء الختامي } & \\
\hline & & 378.00 & 18.90 & 20 & الضابطة & & \\
\hline \multirow{2}{*}{0.276} & \multirow{2}{*}{1.089} & 370.00 & 18.50 & 20 & التجريبية & \multirow{2}{*}{ مجموع المحور } & \\
\hline & & 450.00 & 22.50 & 20 & الضابطة & & \\
\hline 0.282 & 1.076 & 448.50 & 22.43 & 20 & التجريبية & \multicolumn{2}{|l|}{ مهارة تقويم الدرس } \\
\hline
\end{tabular}




\section{المجلة العلمية التربية البدنية وعلوم الرياضة العدد (93) الجزء (1)}

\begin{tabular}{|c|c|c|c|c|c|c|}
\hline & & 371.50 & 18.58 & 20 & الضابطة & \\
\hline \multirow{2}{*}{0.472} & \multirow{2}{*}{0.719} & 383.50 & 19.18 & 20 & التجريبية & \multirow{2}{*}{ مجموع البطاقة } \\
\hline & & 436.50 & 21.83 & 20 & الضابطة & \\
\hline
\end{tabular}

قيمة " ذ " الجدولية عند مستوى معنوية 0.05 = 1.96

يتضح من جدول ( 6 ) تشير نتائج الجدول إلى أنه توجد فروق غير داله داله إحصائياً بين

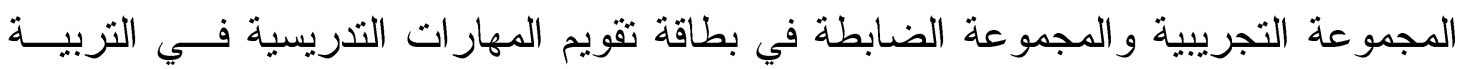

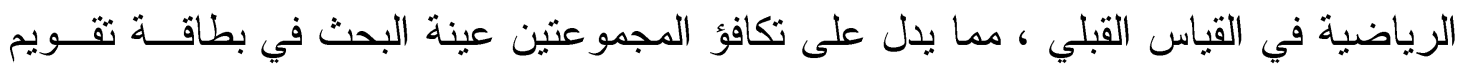
المهارات التدريسية في التربية الرياضية.

$$
\text { جدول ( } 7 \text { ) }
$$

دلاله الفروق بين المجموعة التجريبية و المجموعة الضابطة في بطاقة تقويم المهارات

$$
\text { التدريسية في التزبية الرياضية في القياس البعدي }
$$

\begin{tabular}{|c|c|c|c|c|c|c|c|}
\hline احتمال الخطأ & قيمة " ذ & مجموع الرتب & متوسط الرتب & 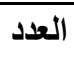 & المجموعة & \multicolumn{2}{|l|}{ المحور } \\
\hline \multirow{2}{*}{0.000} & \multirow{2}{*}{ *5.419 } & 610.00 & 30.50 & 20 & التجريبية & \multirow{2}{*}{\multicolumn{2}{|c|}{ مهارة التخطيط للارس }} \\
\hline & & 210.00 & 10.50 & 20 & الضابطة & & \\
\hline \multirow{2}{*}{0.000} & \multirow{2}{*}{ *5.425 } & 610.00 & 30.50 & 20 & التجريبية & \multirow{2}{*}{ الجزء التمهيدي } & \multirow{8}{*}{ تلنفيذ } \\
\hline & & 210.00 & 10.50 & 20 & الضابطة & & \\
\hline \multirow[b]{2}{*}{0.000} & \multirow[b]{2}{*}{ *5.426 } & 610.00 & 30.50 & 20 & التجريبية & \multirow{2}{*}{ النشاط الترعليمي ( النئيسي } & \\
\hline & & 210.00 & 10.50 & 20 & الضابطة & & \\
\hline \multirow{2}{*}{0.000} & \multirow{2}{*}{ *5.506 } & 610.00 & 30.50 & 20 & التجريبية & \multirow{2}{*}{ الجزء الختامي } & \\
\hline & & 210.00 & 10.50 & 20 & الضابطة & & \\
\hline \multirow{2}{*}{0.000} & \multirow{2}{*}{ *5.416 } & 610.00 & 30.50 & 20 & التجريبية & \multirow{2}{*}{ مجموع المحور } & \\
\hline & & 210.00 & 10.50 & 20 & الضابطة & & \\
\hline \multirow{2}{*}{0.000} & \multirow{2}{*}{ *5.428 } & 610.00 & 30.50 & 20 & التجريبية & \multirow{2}{*}{\multicolumn{2}{|c|}{ مهارة تقويم الدرس }} \\
\hline & & 210.00 & 10.50 & 20 & الضابطة & & \\
\hline \multirow{2}{*}{0.000} & \multirow{2}{*}{ *5.415 } & 610.00 & 30.50 & 20 & التجريبية & \multirow{2}{*}{\multicolumn{2}{|c|}{ مجموع البطاقة }} \\
\hline & & 210.00 & 10.50 & 20 & الضابطة & & \\
\hline
\end{tabular}

قيمة " ذ " الجدولية عند مستوى معنوية 0.05 هى 1.96

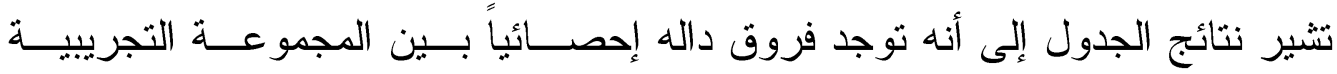

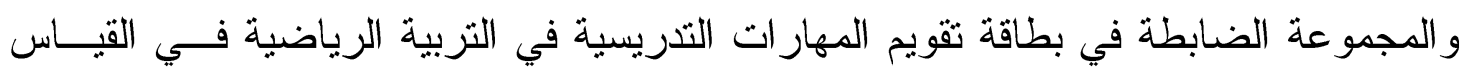
البعدي لصالح المجموعة التجريبية. ويرجع الباحث تقدم المجموعة التجريبية علي المجموعة الضابطة في نتــائج بطاقــة تقـــيم

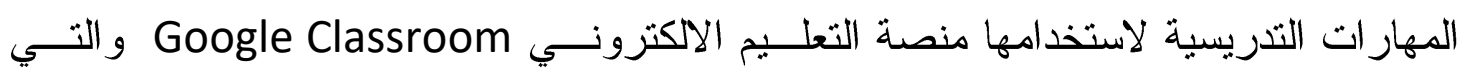

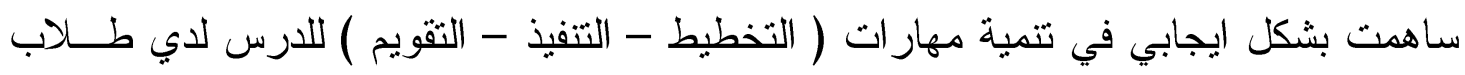

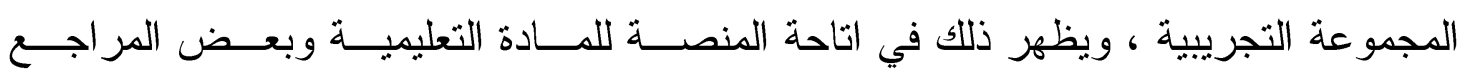
و الفيديو هات المتتوعة والاختبار ات التحصيلية التي ساعدت بدورها في عملية التخطيط الجيد 
للارس ومر اجعة عملية تتفيذ محتوياته ، و القدرة علي الدخول علي المنصة للاستفادة منها في

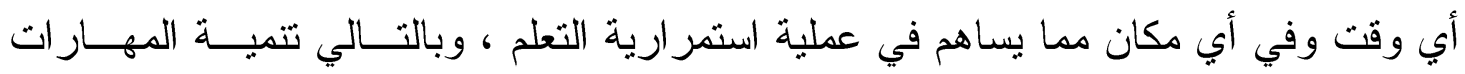
التدريسية لدي الطلاب ، وتتفق هذه النتائج مع دراسة دراسة ساندر ، جولز (2012، Sander (and Golas ايضاً ساعد استخدام منصدة التعليم الالكتروني class room Google مــع المحاضـــــات التدريسية وورش العمل من خلال التدريس المصغر، قد ساعد الطلاب المعلمين في الاشتر الك في بيئة تعلم نشط يستطيعون فيها استخدام تلك الاساليب و الوسائل التكنولوجية كوسيط ووسيلة التئل للتعلم، الأمر الذي قد وفر لهم خبرات أكثر مرونة واتاحة تجارب جديدة لهم، كما وفر قــدرا

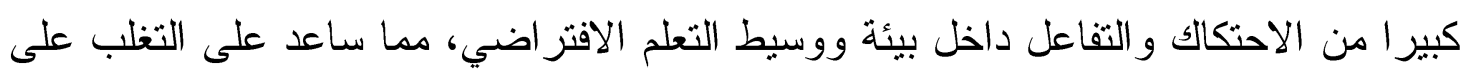
مشكلات ومعوقات التدريس التي تئثر على الكفاءة الذاتية ومستوى الاداء التدريسي.

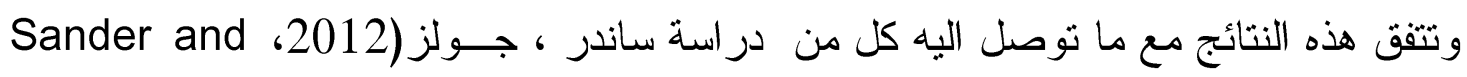

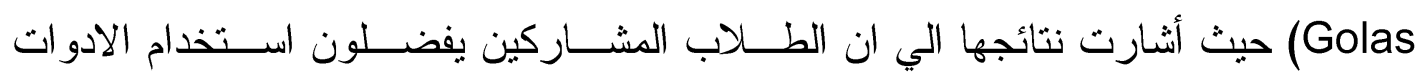

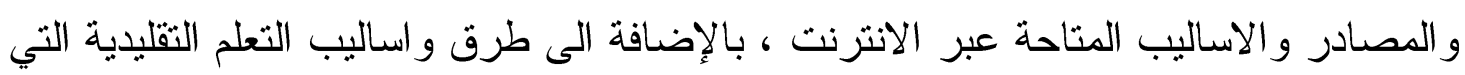

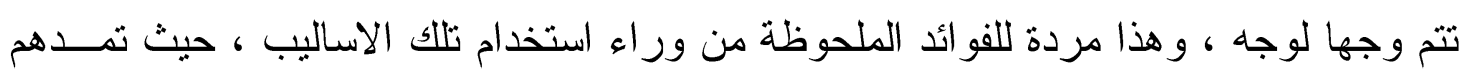

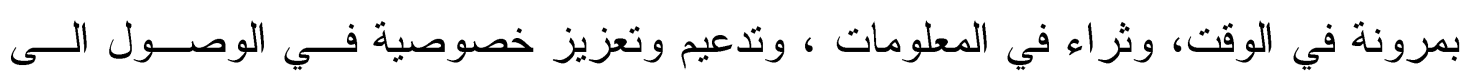

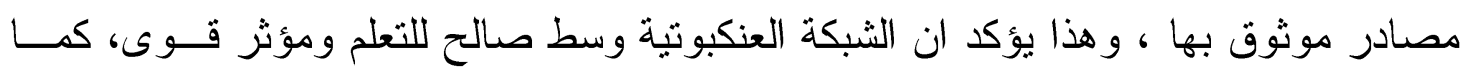
اشارت دراسة (Dillenbourg,2000) ( 14) أن منصة التعليم الالكتروني قد ساعد في احياء

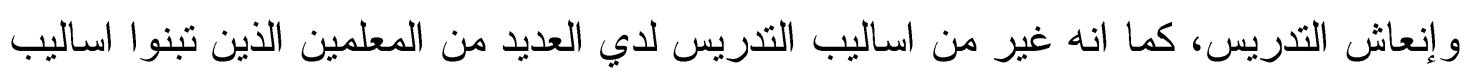

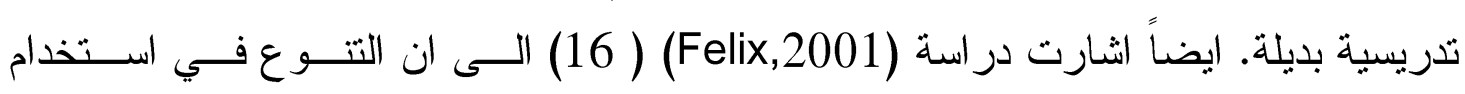

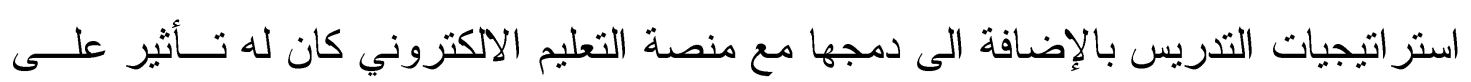
الكفاءة الذاتية للطلاب المعلمين. عرض ومناقثة وتفسير النتائج المتعلقة بالفرض الثاني من فروض البحث و الذي ينص على "

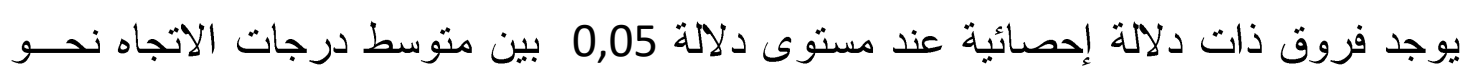

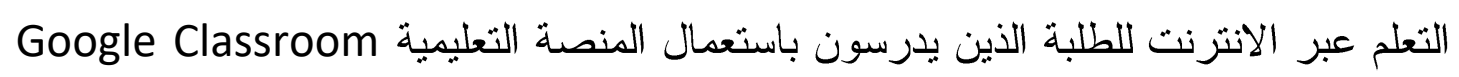

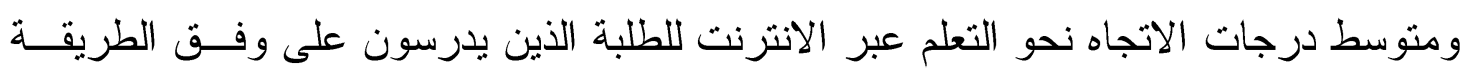
التقليدية. 


\section{المجلة العلمية للثربية البدنية وعلوم الرياضة العدد (93) الجزء (1)}

جدول ( 8 )

دلاله الفروق بين المجموعة التجريبية و المجموعة الضابطة في مقياس الاتجاه نحو التعلم القائم على الإنترنت في القياس القبلي

\begin{tabular}{|c|c|c|c|c|c|c|}
\hline احتمال الخطأ & قيمة " ذ & مجموع الرتب & متوسط الرتب & العدد & المجموعة & المقياس \\
\hline \multirow[b]{2}{*}{0.745} & \multirow[b]{2}{*}{0.325} & 422.00 & 21.10 & 20 & التجريبية & \multirow{2}{*}{ مقياس الاتجاه نحو الألتم على } \\
\hline & & 398.00 & 19.90 & 20 & الضابطة & \\
\hline
\end{tabular}

قيمة " ذ " الجدولية عند مستوى معنوية 0.05 هي 1.96

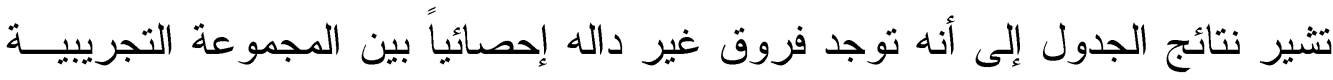

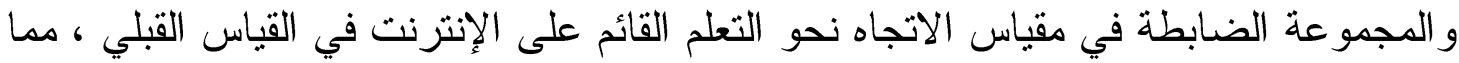
يدل على تكافؤ المجموعتين عينة البحث في قياس الاتجاه نحو التعلم القائم على الإنترنت. جدول ( 9 )

دلاله الفروق بين المجموعة التجريبية و المجموعة الضابطة فى مقياس الاتجاه نحو التعلم القائم على الإنترنت في القياس البعدي

\begin{tabular}{|c|c|c|c|c|c|c|}
\hline احتمال الخطأ & قيمة " ذ & مجموع الرتب & متوسط الرتب & العدد & المجموعة & المقياس \\
\hline \multirow[b]{2}{*}{0.000} & \multirow[b]{2}{*}{$5.413^{*}$} & 610.00 & 30.50 & 20 & التجريبية & \multirow{2}{*}{ التقلم القائم على الإنى } \\
\hline & & 210.00 & 10.50 & 20 & الضابطة & \\
\hline
\end{tabular}

قيمة " ذ " الجدولية عند مستوى معنوية 0.05 هى 1.96

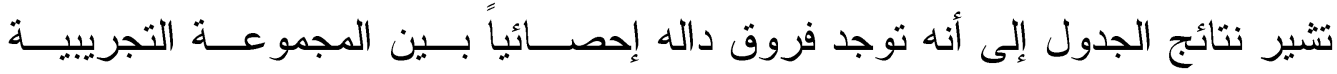

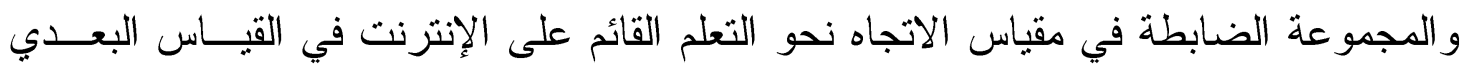
لصالح المجمو عة التجريبية. ويعزو الباحث تقدم المجموعة التجريبية علي المجموعة الضـابطة في مستوي الاتجـــاه نحسـو

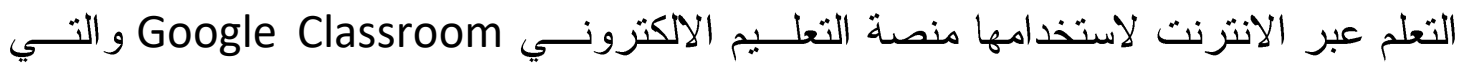
ساهمت بدور ها في تسهيل عملية التواصل واستقبال المعلومات لدي طلاب التثريب الميداني ،

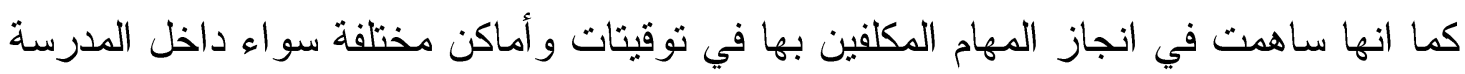

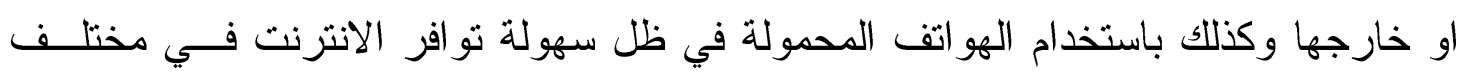

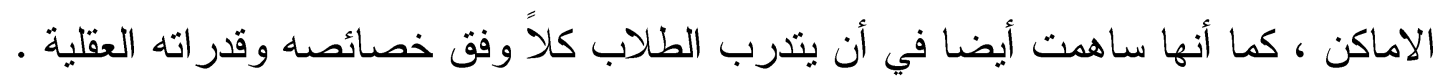

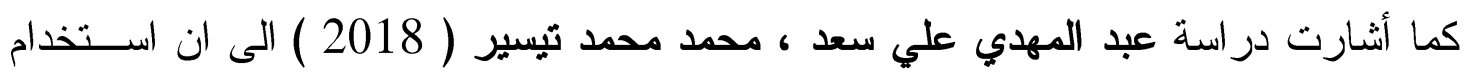

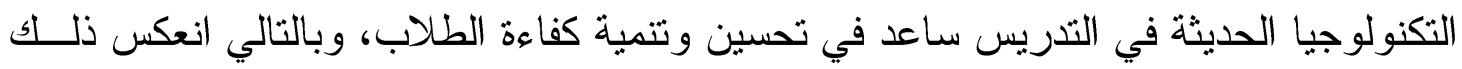
على ادائهم التدريسي حيث اصبحت لديهم الفرصة و القدرة على المثابرة، و الاداء الجيد، القدرة

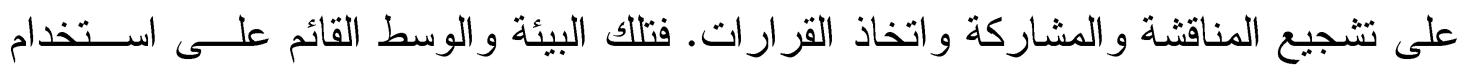




\section{المجلة العلمية التربية البدنية وعلوم الرياضة العدد (93) الجزء (1)}

التكنولوجيا ساعد في بناء الثقة لاى الطلاب المعلمين، كذلك ســـاعد فــي تطـــير اتجاهــات ومو اقف ايجابية نحو التدريس.

وتتفق هذه النتائج مع در اسة كلاً من ماجدة ابر اهيم الباوي ، احمد باسل غازي ( 2019 ) ) ،

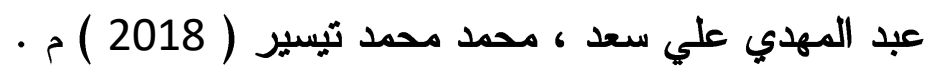

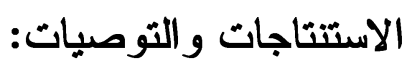

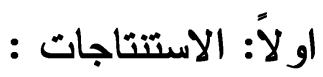

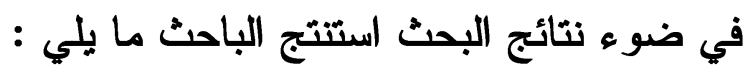

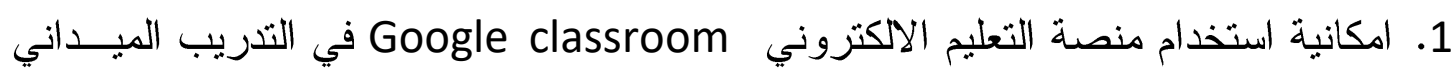
لاي طلاب كلية التربية الرياضية .

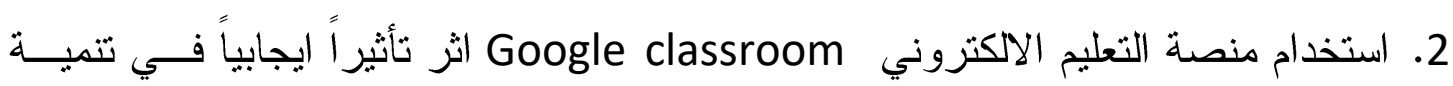
المهار ات التدريسية لدي طلاب التدريب الميداني .

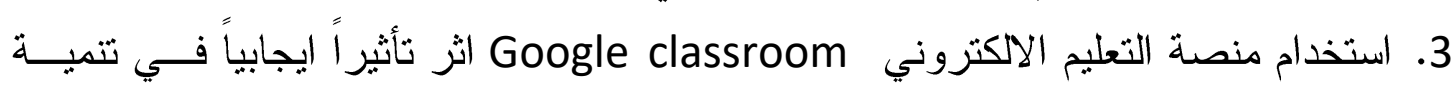
اتجاهات طلاب التدريب الميداني نحو التعلم عبر الانترنت . ثانياً: التوصيات : في ضوء نتائج البحث يوصي الباحث بما يلي :

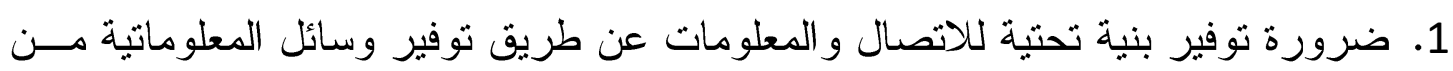

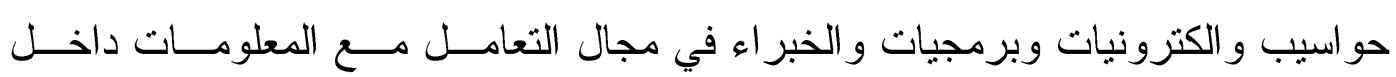
الجامعات وتحديداً كليات التزبية الرياضية .

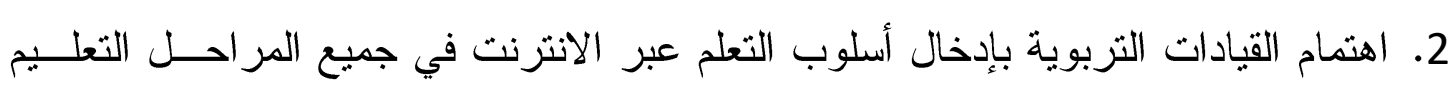

$$
\text { قائمة المراجع : الجامعي : المراجع العربية }
$$

1. السيد محمد مرعي ( 2020 ) م : فاعلية منصة الكترونية قائمة علي الوسائط المتعـددة

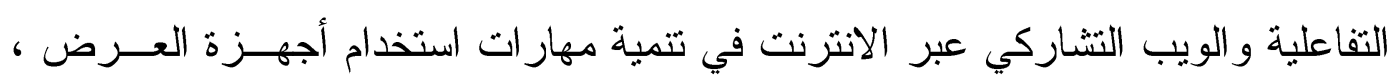

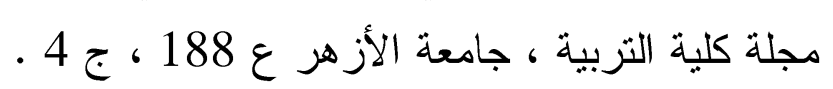

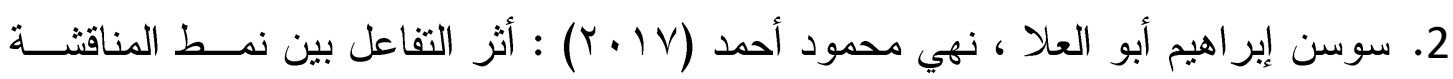

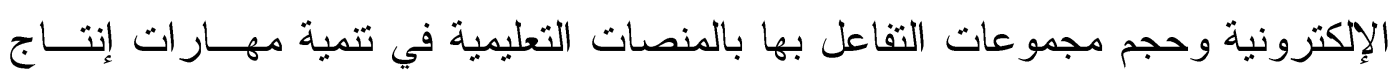

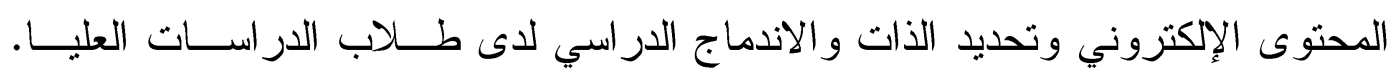

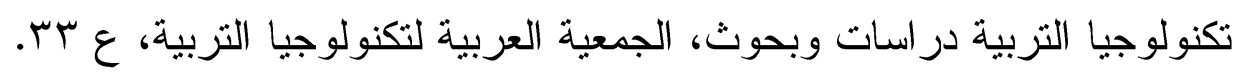


3. عبد العال عبداله السيد ( 2016 ) م : المنصات التعليمية الالكترونيـــ Edomo رؤيسـة

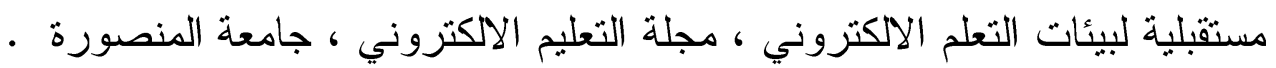

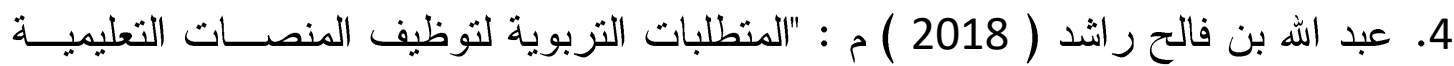

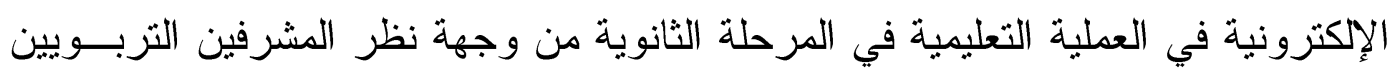

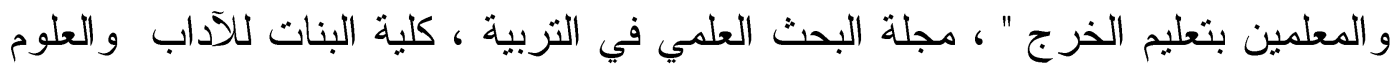

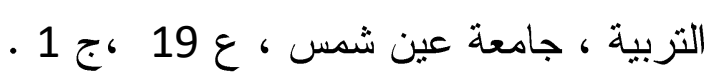

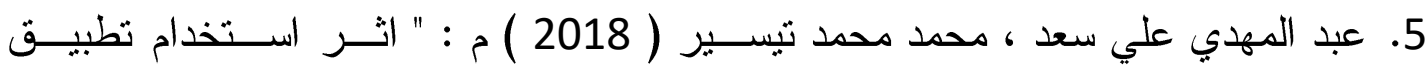
Classroom Google

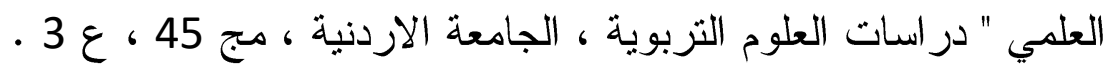

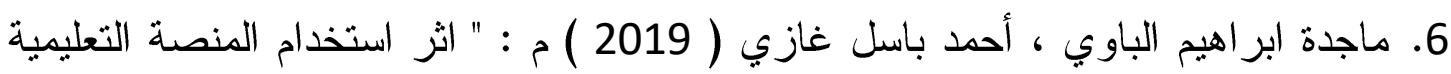

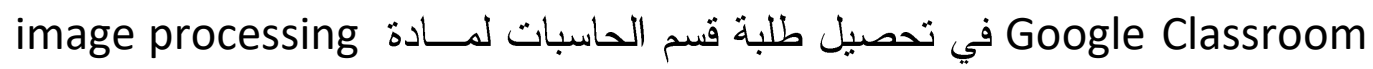

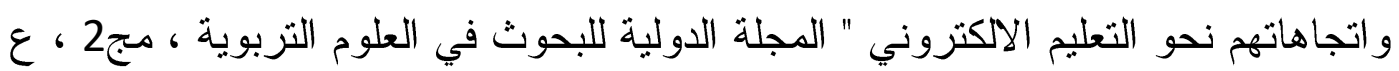
.2

7. محمد حسن حسن رخا ( 2020 ) م : " تطبيق نظام إدارة التعلم الإلكترونـي Google"

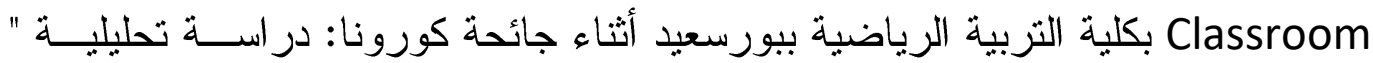
المجلة العلمية للبحوث و الدراسات في التربية الرياضية ، كلية التربية الرياضية ، جامعة الرياضية

$$
\text { بورسعيد، ع عل } 40 .
$$

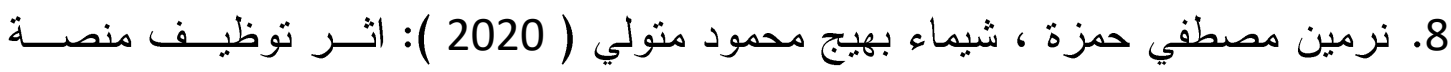

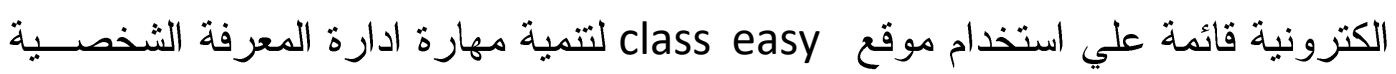

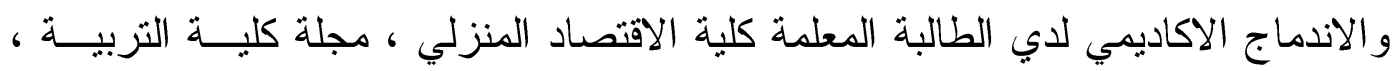

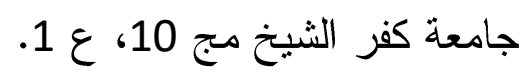

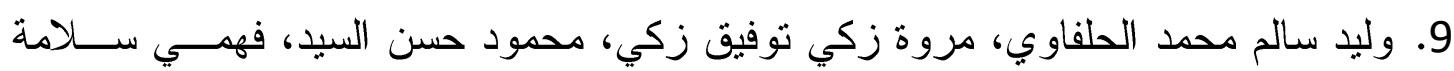

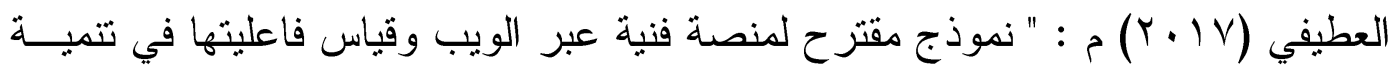

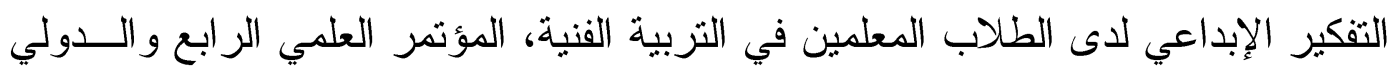

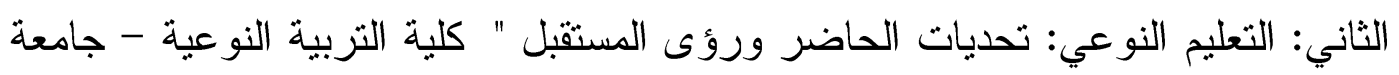

$$
\text { عين شمس. }
$$

$$
\text { ثانياً : المراجع الانجليزية }
$$

10-Sander, B. and Goals, M. (2012). His to viewer: an interactive ELearning plat form Facilitating Group and peer Group Learning. Anat Sci Educ, 6(3):182-191. 


\section{المجلة العلمية التربية البدنية وعلوم الرياضة العدد (93) الجزء (1)}

11-Gedera ,D, Williams, P. John \& Wright, N(2013),An analysis of Moodle in facilitating asynchronous activities in a fully online university course, International Journal of Science and Applied Information Technology (IJSAIT), Vol.2, No.2 .

12-Holmes, M, Tracy, E, Paunter, L, Oestreich, T. \& Park, H,(2015). Moving from Flipcharts to the Flipped Classroom: Using Technology Driven Teaching Methods acceptance and readiness for E-learning in Northeastern Thailand, International Journal of Educational Technology in Higher Education, 13(34).

13-Kasula, A, (2015). Is Google Classroom Ready for EEL.

14-Welch, 1-0:"Education psychology for teaching a modular approach "journal teacher education No,3,1975.

ثالثاً : شبكة المعلومات الدولية

15-https://www.mozn.ws/11553. 


\section{المجلة العلمية للتربية البدنية وعلوم الرياضة العدد (93) الجزء (1)}

\section{ملخص البحث}

"فاعلية استخدام منصة التعليم الاكتروني Google class room علي تتمية المهـارات

التدريسية والاتجــاه نحو التعلم عبر الانترنت لدي طـــلاب التدريب الميداني بكلية التربية

$$
\text { "الرياضية }
$$

م.د// اسلام جمال الدين أحمد خضر

يهدف البحث إلي التعرف علي فاعلية استخدام منصة التعليم الأكترونــي

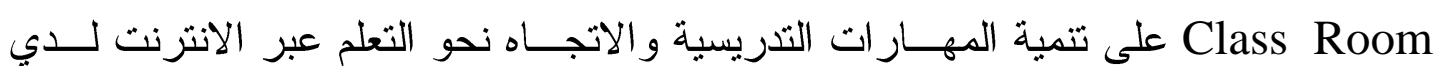

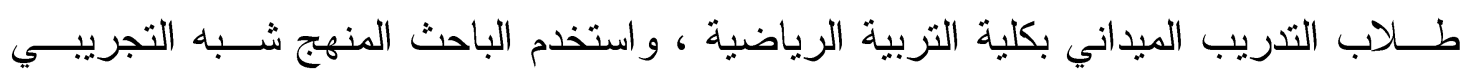

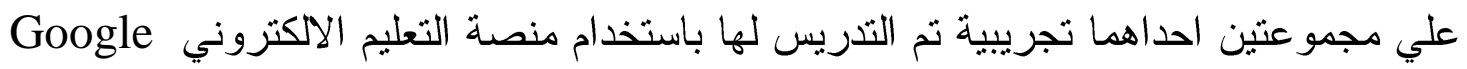

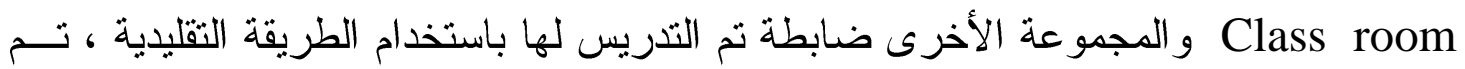

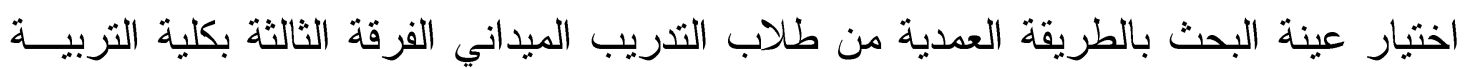

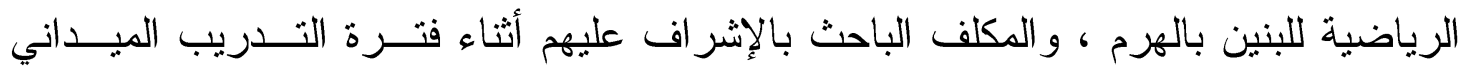

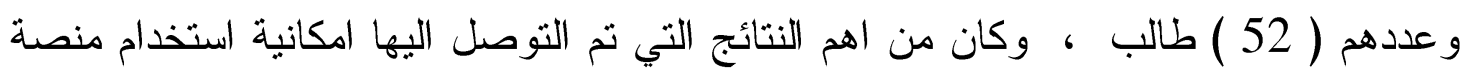

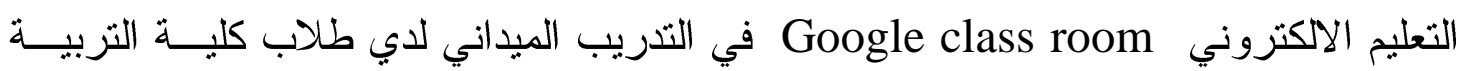

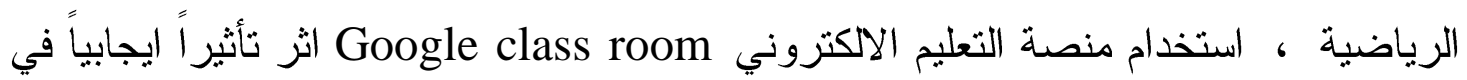
تتمية المهار ات التدريسية لاي طلاب التدريب الميداني ، وكذلك في تتمية اتجاهاتهم نحو التعلم

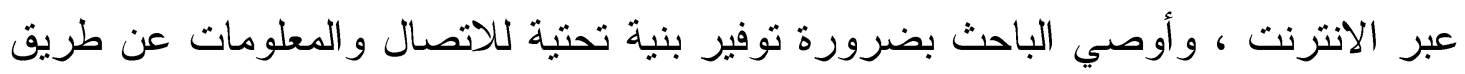

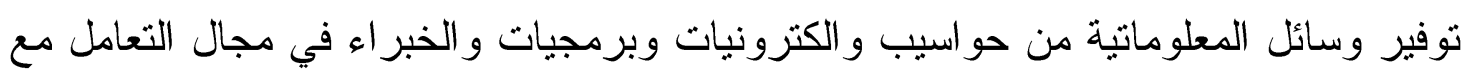

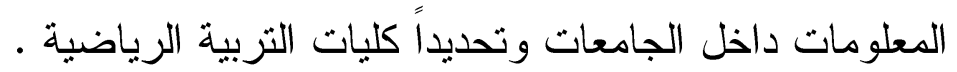




\section{المجلة العلمية اللزبية البدنية وعلوم الرياضة العدد (93) الجزء (1)}

Abstract

The effectiveness of using the Google class room e-learning platform on developing teaching skills and the trend towards online learning among students of field training at the Faculty of Physical Education DR : Eslam Gamal Aldin Ahmed

The research aims to identify the effectiveness of using the Google Class Room e-learning platform on developing teaching skills and the trend towards online learning among field training students at the Faculty of Physical Education. The other is an officer who was taught using the traditional method. The research sample was chosen in a deliberate way from the field training students of the third year at the Faculty of Physical Education for Boys in Al-Haram, and the researcher is assigned to supervise them during the field training period and their number is (52) students, One of the most important results that was reached was the possibility of using the Google class room e-learning platform in field training for students of the Faculty of Physical Education. The Internet, and the researcher recommended the need to provide an infrastructure for communication and information by providing informational means of computers, electronics, software and experts in the field of dealing with information within universities, specifically faculties of physical education 